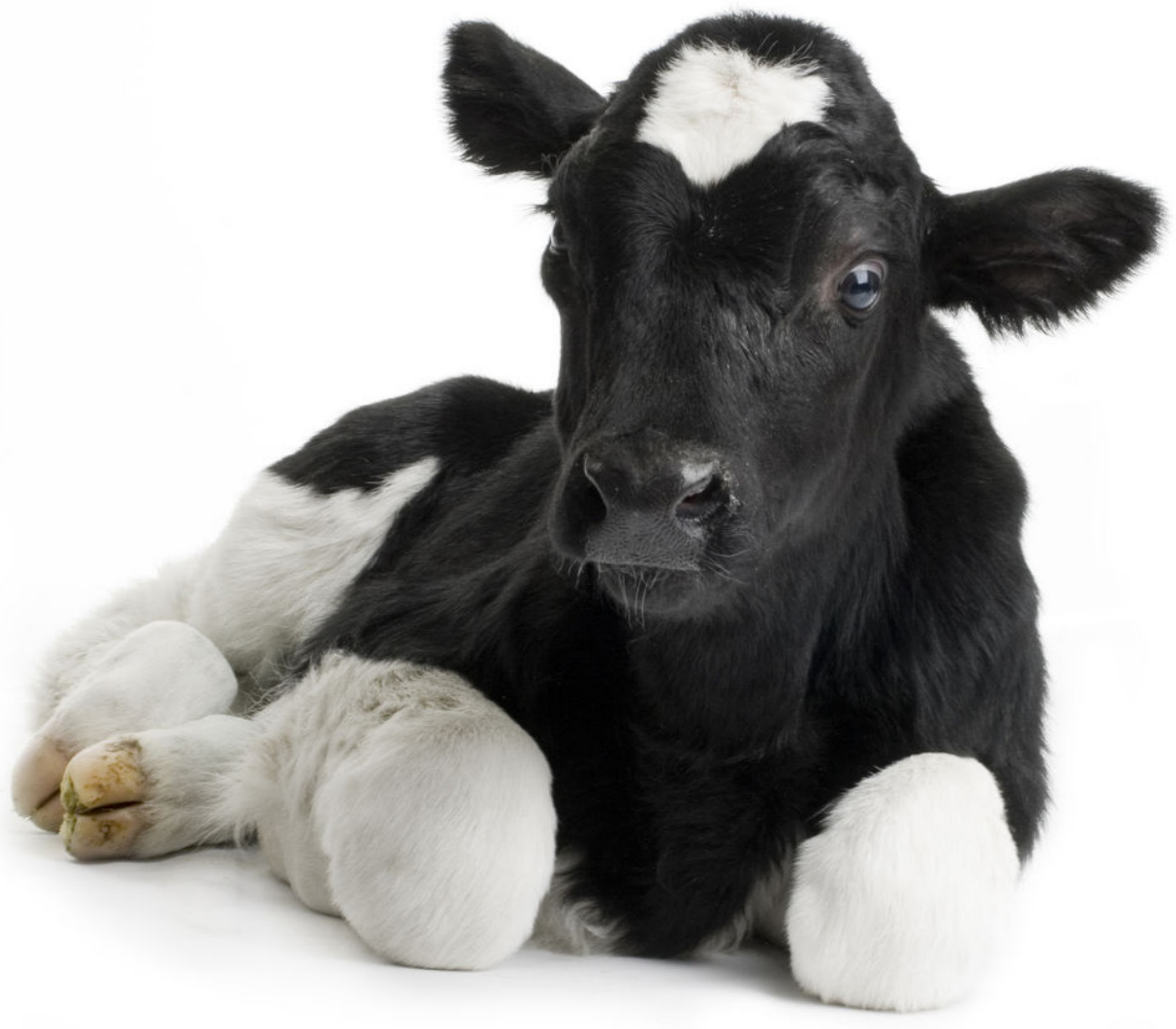

Effect of solid feed level and types of roughage on passage kinetics of milk replacer, concentrates, and roughage in veal calves

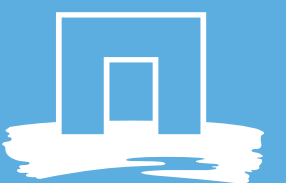





\section{Effect of solid feed level and types of roughage on passage kinetics of milk replacer, concentrates, and roughage in veal calves}

Sanne van Gastelen ${ }^{1}$, Annemarie J.W. Mens ${ }^{1}$, Gisabeth P. Binnendijk ${ }^{1}$, and Walter J.J. Gerrits ${ }^{2}$

${ }^{1}$ Wageningen Livestock Research, Wageningen University \& Research, P.O. Box 338, $6700 \mathrm{AH}$, Wageningen, the Netherlands

${ }^{2}$ Animal Nutrition Group, Wageningen University \& Research, P.O. Box 338, $6700 \mathrm{AH}$, Wageningen, the Netherlands

This research was conducted by Wageningen University \& Research, within the framework of the public private partnership "TKI-AF-12064, Duurzame verbreding grondstoffenpakket voor vleeskalveren", and financially supported by the Ministry of Agriculture, Nature and Food Quality and Stichting Brancheorganisatie Kalversector.

Wageningen Livestock Research

Wageningen, February 2020

Report 1246 
Van Gastelen, S., A. J. W. Mens, G. P. Binnendijk, and W. J. J. Gerrits, 2020. Effect of solid feed level and types of roughage on passage kinetics of milk replacer, concentrates, and roughage in veal calves. Wageningen Livestock Research, Report 1246.

\section{Nederlandse samenvatting - Het effect van de hoeveelheid ruw- en krachtvoer en van het type ruwvoer op de passage kinetiek van kalvermelk, krachtvoer en ruwvoer in vleeskalveren.}

Traditioneel werd aan vleeskalveren alleen kalvermelk gevoerd. Sinds eind jaren 90 wordt naast kalvermelk ook ruw- en krachtvoer verstrekt, in eerste instantie opgelegd door EU regelgeving, daarna in toenemende mate omdat ruw- en krachtvoer goedkopere nutriëntleveranciers zijn dan kalvermelk. Daarbij groeide het besef, onderbouwd door wetenschappelijk onderzoek, dat het verstrekken van voldoende ruw- en krachtvoer positieve effecten heeft op gedrag en gezondheid, en daarmee het welzijn, van vleeskalveren. Bij een kalf is nog steeds minimaal $50 \%$ van de nutriëntvoorziening afkomstig van kalvermelk, hoewel ruw- en krachtvoeders een belangrijker aandeel van het hedendaagse rantsoen voor het kalf uitmaken.

Bij vleeskalveren is weinig bekend over de manier waarop kracht- en ruwvoeders de ontwikkeling van de pensmotiliteit, en daarmee de passage van voerdeeltjes door de pens, beïnvloeden. Dit heeft geresulteerd in de volgende onderzoeksvraag: hoe verlopen de passage door de pens en de pensfermentatie van ruw- en krachtvoercomponenten bij een vleeskalf? Om deze vraag te beantwoorden werd een proef uitgevoerd met 48 vleeskalveren van 6 weken leeftijd aan de start van de proef. Deze kalveren werden random toegewezen aan 1 van de 4 behandelingen (d.w.z. 12 kalveren per behandeling). Drie behandelingen hadden kort stro als ruwvoer, waarbij de krachtvoer tot ruwvoer verhouding 90:10 was. De hoeveelheid ruw- plus krachtvoeder varieerde van $20 \mathrm{~g} / \mathrm{kg}$ metabool lichaamsgewicht / dag (LowSF), naar $30 \mathrm{~g} / \mathrm{kg}$ metabool lichaamsgewicht / dag (MiddleSF), naar 40 $\mathrm{g} / \mathrm{kg}$ metabool lichaamsgewicht / dag (HighSF). De vierde behandeling (Hay) had lang hooi als ruwvoer, waarbij de krachtvoer tot ruwvoer verhouding 70:30 was. De hoeveelheid ruw- plus krachtvoer was gelijk aan de HighSF behandeling, namelijk $40 \mathrm{~g} \mathrm{/} \mathrm{kg} \mathrm{metabool} \mathrm{lichaamsgewicht} \mathrm{/} \mathrm{dag.} \mathrm{De}$ hoeveelheid kalvermelk was vastgezet op de HighSF behandeling, namelijk $39 \mathrm{~g} \mathrm{/} \mathrm{kg} \mathrm{metabool}$ lichaamsgewicht / dag, waarbij de hoeveelheid kalvermelk voor de andere behandelingen werd bepaald op basis van een pair gain strategy om een gelijke lichaamsgroei over de behandelingen heen te realiseren. Een gelijk lichaamsgewicht tijdens de meetperiode werd ook gerealiseerd door de kalveren met het hoogste lichaamsgewicht een korte adaptatieperiode (van 6 weken) toe te wijzen en de kalveren met het laagste lichaamsgewicht een lange adaptatieperiode (van 9 weken) toe te wijzen. Bij de start van de metingen van de passage van voerdeeltjes waren de kalveren 12 tot 15 weken oud, met een gemiddeld lichaamsgewicht van $123 \pm 6.1 \mathrm{~kg}$.

Tijdens de meetperiode van 2 weken, werd de passage van voerdeeltjes door het maagdarmkanaal op twee verschillende manieren gemeten. Allereerst door middel van fecale excretiecurves gedurende 1 week na een orale puls dosis van drie onverteerbare markeerstoffen: (1) cobalt-EDTA (Co-EDTA) als markeerstof voor kalvermelk, (2) ytterbium $\left(\mathrm{Yb}_{2} \mathrm{O}_{3}\right)$ als markeerstof voor krachtvoer en (3) chroom ( $\mathrm{Cr}$ ) gewassen ruwvoer als markeerstof voor ruwvoer. Uit deze excretiecurves kan de gemiddelde verblijftijd van digesta in het hele maagdarmkanaal worden gemeten. Daarnaast kan de vorm van de curve na de piek worden gebruikt om de passagesnelheid door het traagste compartiment (waarschijnlijk de pens) te schatten. Verder werd voor het bepalen van passagegedrag van voerdeeltjes gebruik gemaakt van ${ }^{13} \mathrm{CO}_{2}$ excretiepatronen gedurende 1 week na toediening van een eenmalige dosering van een natuurlijk ${ }^{13} \mathrm{C}$ verrijkt bacterieel eiwit (voor het krachtvoer) en ${ }^{13} \mathrm{C}$ verrijkt octaanzuur (ook voor het krachtvoer). De ${ }^{13} \mathrm{CO}_{2}$ excretiepatronen zijn een maat voor verschuivingen in passagegedrag van de voerdeeltjes onder invloed van de behandelingen. De kalveren verschillen 1 week in leeftijd tussen beide methoden om passage van voerdeeltjes door het maagdarmkanaal te meten en aan het einde van de proef waren de kalveren 14 tot 17 weken oud.

De fecale excretiecurves van co-EDTA en $\mathrm{Yb}_{2} \mathrm{O}_{3}$ werden niet beïnvloed door de verschillende behandelingen. Dat betekent dat de gemiddelde verblijfsduur van zowel de kalvermelk als van het krachtvoer in het maagdarmkanaal, 12,4 uur voor de kalvermelk en 21,4 uur voor het krachtvoer, vergelijkbaar is, ongeacht de totale hoeveelheid van ruw- plus krachtvoeder, of van het type ruwvoer. 
De excretiecurves van $\mathrm{Cr}$ gewassen ruwvoer werd wel beïnvloed door de verschillende behandelingen. Het lange hooi van de Hay behandeling had een beduidend snellere passage (36,8 uur) door het maagdarmkanaal dan het korte stro van de andere behandelingen (gemiddeld 59,1 uur). Het verschil tussen beide soorten ruwvoeders, kort stro en lang hooi, wordt naar alle waarschijnlijkheid veroorzaakt door het verschil in verteerbaarheid, alsmede verschil in effect van het ruwvoeder op de ontwikkeling en het functioneren van de pens. Stro heeft ruwweg een $42 \%$ verteerbaarheid van organische stof, terwijl hooi ruwweg een $70 \%$ verteerbaarheid van organische stof heeft. Als een grondstof beter wordt verteerd, zal het doorgaans sneller het maagdarmkanaal passeren. Daarnaast stimuleert lang hooi herkauwactiviteit met een verhoogde speekselproductie tot gevolg. Dit laatste verhoogt de buffercapaciteit van de pens(vloeistof), wat resulteert in een betere vertering, alsmede de ontwikkeling van penspapillen. Ook zorgen langere voerdeeltjes doorgaans voor een betere pens motiliteit.

Uit de excretiecurves van Cr gewassen ruwvoer kan ook geconcludeerd worden dat de passagesnelheid van het korte stro door het volledige maagdarmkanaal niet beïnvloed wordt door de verschillende hoeveelheden ruw- en krachtvoeders. Dit is het tegenovergestelde van wat doorgaans wordt waargenomen bij volwassen runderen, waarbij een verhoogde voeropname de passage snelheid verhoogt met een kortere verblijfsduur in de pens tot gevolg. Bij kalveren van deze leeftijd (12-15 weken) is de pens nog in ontwikkeling en ontvangen zij ruwweg 50\% van de nutriëntvoorziening uit kalvermelk. Hierdoor is het kalf tot op zekere hoogte te vergelijken met éénmagige dieren. Bij varkens is recentelijk aangetoond dat een verhoogde voeropname de verblijfduur in de maag juist verhoogt. Het niet duidelijk vinden van een effect, of tegenstrijdig met wat verwacht wordt, van de hoeveelheid ruwen krachtvoeders op de passagesnelheid van ruwvoer in kalveren heeft wellicht te maken met het feit dat de pens nog in ontwikkeling is en het maagdarmkanaal zich dus niet éénduidig als dat van een herkauwer dan wel van een eenmagig dier gedraagt. Dit wordt bevestigd door de geschatte fractionele passage van de ruwvoeders door de pens. Deze fractionele passage snelheid (\% / uur) was negatief gecorreleerd aan de hoeveelheid ruw- en krachtvoer van het rantsoen $(r=-0.32)$.

De ${ }^{13} \mathrm{CO}_{2}$ excretiepatronen na toedienen van ${ }^{13} \mathrm{C}$ verrijkt octaanzuur laten zien dat octaanzuur geen geschikte marker is voor het meten van de passagesnelheid van het krachtvoer. Daarnaast werden er geen duidelijk ${ }^{13} \mathrm{CO}_{2}$ excretiepatronen waargenomen (d.w.z. niet anders dan de achtergrondverrijking) na toediening van ${ }^{13} \mathrm{C}$ verrijkt bacterieel eiwit, waardoor we op basis van het bacterieel eiwit weinig kunnen zeggen over de passage van het krachtvoer. De ${ }^{13} \mathrm{CO}_{2}$ excretiepatronen zijn geen alternatief voor de fecale excretiecurves, omdat de passage snelheid (en daarmee ook de verblijfsduur) sterk tussen beiden methoden verschillen en niet met elkaar correleren.

Samenvattend, op basis van deze studie kunnen we concluderen dat het niveau van ruw- en krachtvoer (ten opzichte van de hoeveelheid kalvermelk) geen effect heeft op de passagesnelheid van de verschillende rantsoen componenten (d.w.z. kalvermelk, krachtvoer en ruwvoer) door het maagdarmkanaal bij vleeskalveren. Hoewel er op verschillende niveaus interactie tussen het aandeel kalvermelk en ruw- plus krachtvoer zou kunnen plaatsvinden (bijvoorbeeld op stikstof niveau), impliceren deze resultaten dat deze potentiele interacties niet leiden tot een minder stabiel verteringssysteem waarin sprake kan zijn van onvoorspelbare effecten op verschillende verteringsprocessen. Het type ruwvoer (lang hooi t.o.v. kort stro) heeft invloed op de passage door de pens en het volledige maagdarmkanaal bij vleeskalveren. 
This report can be downloaded for free at https://doi.org/10.18174/519750 or at www.wur.nl/livestock-research (under Wageningen Livestock Research publications).

(C) 2020 Wageningen Livestock Research

P.O. Box 338, $6700 \mathrm{AH}$ Wageningen, The Netherlands, T +31 (0)317 4839 53,

E info.livestockresearch@wur.nl, www.wur.nl/livestock-research. Wageningen Livestock Research is part of Wageningen University \& Research.

All rights reserved. No part of this publication may be reproduced and/or made public, whether by print, photocopy, microfilm or any other means, without the prior permission of the publisher or author.

Wageningen Livestock Research is NEN-EN-ISO 9001:2015 certified.

All our research commissions are in line with the Terms and Conditions of the Animal Sciences Group. These are filed with the District Court of Zwolle.

Wageningen Livestock Research Report 1246 


\section{Table of contents}

$\begin{array}{ll}\text { Abstract } & 7\end{array}$

1

$\begin{array}{ll}\text { Introduction } & 8\end{array}$

2

$\begin{array}{ll}\text { Materials and Methods } & 9\end{array}$

$2.1 \quad$ Animals and Housing $\quad 9$

2.2 Diets 9

2.3 Adaptation $\quad 9$

2.3.1 Feeding 10

$\begin{array}{lll}2.4 & \text { Breath Tests } & 10\end{array}$

2.4.1 Feeding 10

2.4.2 Measurements 10

2.4.3 Calculations 11

2.5 Fecal Excretion Curves $\quad 12$

2.5.1 Feeding 12

2.5.2 Measurements 12

2.5.3 Calculations $\quad 12$

2.6 Chemical Analyses 13

2.7 Statistical Analyses $\quad 14$

$\begin{array}{llr}3 & \text { Results } & 15\end{array}$

$\begin{array}{lll}3.1 & \text { Animal Performance } & 15\end{array}$

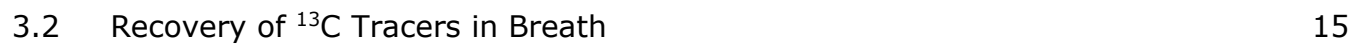

3.3 Fecal Excretion Curves of Ingestible Markers $\quad 15$

3.3.1 Milk Replacer $\quad 15$

$\begin{array}{ll}3.3 .2 \text { Concentrates } & 15\end{array}$

$\begin{array}{ll}3.3 .3 \text { Roughage } & 16\end{array}$

$\begin{array}{llr}4 & \text { Discussion } & 24\end{array}$

4.1 Fecal Excretion Curves of Ingestible Markers $\quad 24$

$\begin{array}{lll}4.2 & \text { Multicompartmental Model } & 25\end{array}$

$\begin{array}{lll}4.3 & \text { Recovery of }{ }^{13} \mathrm{C} \text { Tracers in Breath } & 26\end{array}$

5

Conclusions

27

6

Acknowledgments

28

References

29 


\section{Abstract}

The aims of this study were (1) to determine the effect of solid feed (SF) level and type of roughage on passage kinetics of milk replacer (MR), concentrates, roughage in veal calves, and (2) to compare passage kinetics of concentrates measured by the fecal excretion curves of indigestible markers with the non-invasive ${ }^{13} \mathrm{C}$ tracer breath test. In total, 48 Holstein-Friesian calves (6 weeks of age; $68 \pm 7.7$ $\mathrm{kg}$ of BW) were assigned to 1 of the 4 dietary treatments. Three treatments contained chopped straw as roughage in the SF mixture in a concentrate to roughage ratio of 90:10 (as fed). The SF level varied, being $20 \mathrm{~g} / \mathrm{kg} \mathrm{BW}^{0.75} / \mathrm{d}$ (LowSF), $30 \mathrm{~g} / \mathrm{kg} \mathrm{BW}^{0.75} / \mathrm{d}$ (MiddleSF), or $40 \mathrm{~g} / \mathrm{kg} \mathrm{BW}^{0.75} / \mathrm{d}$ (HighSF). The fourth treatment (Hay) contained long hay as roughage in the SF mixture in a concentrate to roughage ratio of 70:30 (as fed). The SF level of the Hay treatment was similar to the HighSF treatment, viz. 40 $\mathrm{g} / \mathrm{kg} \mathrm{BW}^{0.75} / \mathrm{d}$. The quantity of MR was fixed for the HighSF treatment (i.e., $39 \mathrm{~g} / \mathrm{kg} \mathrm{BW}^{0.75} / \mathrm{d}$ ) and during the adaptation period, the amount of MR for the other treatments was calculated based on a pair gain strategy, to achieve comparable body weight gain (BWG) across treatments. Passage kinetics were estimated using the recovery of ${ }^{13} \mathrm{C}$ from a pulsed-dose $\left[1-{ }^{13} \mathrm{C}\right]$ octanoate with the concentrate or a pulsed-dose low-enriched bacterial protein in the concentrate, in breath measured in respiration chambers. The estimated time to peak enrichment was corrected for the time to peak enrichment following an intravenous injection of $\left[{ }^{13} \mathrm{C}\right]$ sodium bicarbonate. Passage kinetics were estimated from fecal excretion curves obtained after ingestion of the chromium-mordanted straw (i.e., for LowSF, MiddleSF, and HighSF treatments) or hay (i.e., for Hay treatment) as a marker for the roughage, $2 \mathrm{~g}$ of Ytterbium(II)Oxide as a marker for concentrate, and $9 \mathrm{~g}$ of cobalt(II)EDTA as a marker for the MR. The results of the fecal excretion curves show that the total-tract retention of MR was, on average, $12.4 \mathrm{~h}$, and that the passage kinetic of MR was not affected by the level of SF. Additionally, the total-tract retention of concentrates was shorter (on average $21.4 \mathrm{~h}$ ) than that of both straw $(59.1 \mathrm{~h}$ ) and hay $(36.8 \mathrm{~h})$, and was not affected by the level of SF. Furthermore, the passage of roughage, both through the rumen and through the total digestive tract, was affected by level of SF as well as type of roughage. Long hay increased time to peak by (on average) $22.3 \mathrm{~h}(P=0.004)$ relative to the chopped straw containing treatments. Hence, the passage rate of long hay is higher and subsequently the mean retention time in the gastro-intestinal tract shorter than that of chopped straw. Additionally, the fractional passage rate of the slowest compartment was related with SF level $(r=-0.32, P=0.049)$, suggesting that the fractional passage rate of the rumen decreases with increasing SF level likely due to the effect of SF level on rumen volume. The results of the ${ }^{13} \mathrm{C}$ breath test show that $\left[1-{ }^{13} \mathrm{C}\right]$ octanoate cannot serve as an alternative to measure passage kinetics of concentrates through the digestive tract of veal calves. Overall, this study provides estimates of digesta passage kinetics of MR, concentrates and roughage that can be used in digestion modelling. It is concluded that the potential interactions between MR and SF occurring in the gastro-intestinal tract, do not complicate the prediction of the nutritional value of these ration components, and that the non-invasive ${ }^{13} \mathrm{C}$ tracer breath test approach cannot serve as an alternative to the fecal excretion curves of indigestible markers to determine passage kinetics of concentrates in veal calves. 


\section{Introduction}

In veal calf nutrition, there is a strong incentive to replace a considerable portion of the milk replacer (MR) by solid feeds (SF) in the diet. Since the introduction of a compulsory portion of solid feed provision to calves in the EU (European Union 97/2/EC Directive by the EU Council), the proportion of metabolizable energy intake from solid feed has increased in veal calves to $30-50 \%$ in the Netherlands.

Interactions between MR and SF occurring in the gastro-intestinal tract, complicate the prediction of the nutritional value of these ration components. Quantitative information about passage kinetics of SF through the rumen and other gastro-intestinal compartments of veal calves is limited. In dairy calves, it was shown that decreasing MR intake (i.e., 30 and 60\% relative to the control treatment) resulted in increased SF intake as well as increased ruminal fractional passage rate (Broesder et al., 1990). Similar, Berends et al. (2015) demonstrated that an increased SF level (from $1.2 \mathrm{~kg}$ of DM/d to $3.0 \mathrm{~kg} \mathrm{DM} / \mathrm{d}$ ) increased the rumen fractional passage rate of both concentrates and straw $(3.3$ and $1.3 \% / h$ for the low SF level, respectively, and 4.9 and $1.7 \%$ h for the high SF level, respectively) in veal calves at 27 weeks of age. This effect on ruminal passage rate appeared to be stronger for concentrates than that for straw. It was concluded that increasing SF level introduces large variation in passage kinetics of dietary components, predominantly in the rumen compartment (Berends et al., 2015). To the best of our knowledge, passage kinetics of different ration components and its potential impact on the nutritional value of SF as well as the potential of nutrient recycling via the rumen has not been investigated in younger veal calves.

Studies for measuring passage kinetics in ruminants traditionally involve the recovery of a pulsed-dose indigestible tracer inside various compartments of the gastro-intestinal tract (e.g., Berends et al., 2015), or fecal excretion curves of pulsed-dosed indigestible markers (e.g., Udén et al., 1980). The first technique involves sacrificing experimental animals, thus preventing repeated measurements on a subject. The latter technique requires frequent collection of feces, often performed during individual housing on balance cages. Novel technologies to measure passage kinetics include the measurement of abomasum emptying from appearance of an oral acetaminophen dose in blood plasma (e.g., Labussière et al., 2014; Stahel et al., 2017) as well as measurements of recovery of ${ }^{13} \mathrm{C}$ tracers in breath. Various ${ }^{13} \mathrm{C}$ breath test applications are used in humans and animals (McCue and Welch, 2016). This technique has however not been tested and validated in calves for determination of passage rate kinetics of ration components.

Hence, the aims of this study were (1) to provide reliable estimates of total tract mean retention times of MR, concentrates, and roughage, (2) to determine the effect of SF level and type of roughage on passage kinetics of MR, concentrates, roughage in veal calves, and (3) to compare passage kinetics in veal calves using the fecal excretion curves of indigestible markers as well as a non-invasive ${ }^{13} \mathrm{C}$ tracer breath test approach to determine whether the later technique can serve as an alternative. 


\section{Materials and Methods}

This study was conducted from September 2017 until March 2018 at the animal research facilities of Wageningen University \& Research (Wageningen, the Netherlands)], in accordance with Dutch law and approved by the Central Committee of Animal Experiments (The Hague, the Netherlands).

\subsection{Animals and Housing}

In total, 48 Holstein-Friesian calves ( 6 weeks of age; $68 \pm 7.7 \mathrm{~kg}$ of BW) were purchased from commercial veal calf farms and selected based on uniformity and clinical health. The 48 calves could not be housed simultaneously, hence calves arrived in 2 batches of 24 calves each, following the exact same procedure and timeline.

\section{$2.2 \quad$ Diets}

The 4 dietary treatments consisted of different levels of SF as well as different types of roughage in the SF mixture (Table 1). Three treatments contained chopped straw as roughage in the SF mixture in a concentrate to roughage ratio of $90: 10$ (as fed). The SF level was $20 \mathrm{~g} / \mathrm{kg} \mathrm{BW}^{0.75} / \mathrm{d}$ (LowSF), $30 \mathrm{~g} / \mathrm{kg}$ $\mathrm{BW}^{0.75} / \mathrm{d}$ (MiddleSF), or $40 \mathrm{~g} / \mathrm{kg} \mathrm{BW}^{0.75} / \mathrm{d}$ (HighSF). The fourth treatment (Hay) contained long hay as roughage in the SF mixture in a concentrate to roughage ratio of 70:30 (as fed). The SF level of the Hay treatment was similar to the HighSF treatment, viz. $40 \mathrm{~g} / \mathrm{kg} \mathrm{BW} 0.75 / \mathrm{d}$. Based on our expected maximum voluntary intake, the quantity of MR was fixed for the HighSF treatment (i.e., $39 \mathrm{~g} / \mathrm{kg} \mathrm{BW} 0.75 / \mathrm{d}$ ) and during the adaptation period, the amount of MR for the other treatments was calculated based on a pair gain strategy, to achieve similar body weight gain (BWG) across treatments. After the adaptation period (i.e., shortest duration was 5 weeks), the quantity of MR for the other treatments was fixed to the levels reported in Table 1.

The same MR (produced by Denkavit, Voorthuizen, the Netherlands) was used for all 4 treatments, whereas the concentrates were adjusted to the type of roughage fed, based on equal protein content of the SF mixture. Both concentrates were produced as a mash by Denkavit (Voorthuizen, the Netherlands) with mineral premix produced by Twilmij B.V. (Stroe, the Netherlands). Table 2 shows the nutrient and chemical composition of the different feed components (i.e., MR, concentrates, and roughages).

\subsection{Adaptation}

Within each batch, calves were allocated to pens ( 6 calves per pen; 4 pens) based on BW to ensure similar mean BW across pens. The pens were randomly assigned to 1 of the 4 dietary treatments. Upon arrival, calves were adapted to the designated dietary treatment in order to allow rumen development and to become adapted to the levels and composition of SF. During the adaptation period, calves were housed in groups of 6 calves per pen ( 3 by $3 \mathrm{~m}$ ) equipped with wooded-slatted floors and fences.

The experiment followed a staggered time-line due to the limited capacity of the climate respiration chambers (CRC). Hence, the adaptation period lasted 6 to 9 weeks (Figure 1). After 4 weeks of adaptation, the calves within a pen were paired according to BW, resulting in 3 pairs per pen (\#1 to \#3) with increased mean BW. Striving for equal BW upon measurements, the pair of calves with the highest BW had the shortest adaptation period (i.e., 6 weeks) and the pair of calves with the lowest BW had the longest adaptation period (i.e., 9 weeks). The mean BW of the calves at the end of the adaptation period was $117 \pm 3.4 \mathrm{~kg}, 115 \pm 3.9 \mathrm{~kg}, 126 \pm 7.7 \mathrm{~kg}, 127 \pm 8.9 \mathrm{~kg}, 125 \pm 3.5 \mathrm{~kg}$, and $130 \pm 8.9 \mathrm{~kg}$ for pairs 1,2 , and 3 of batch 1 and pairs 1,2 , and 3 of batch 2 , respectively. 


\subsubsection{Feeding}

During the adaptation period, calves were allowed ad libitum access to water provided via drinking nipples. The concentration of MR was $130 \mathrm{~g} / \mathrm{L}$ and was supplied individually in buckets at 40 to $42^{\circ} \mathrm{C}$, provided twice daily in equally sized meals at $0730 \mathrm{~h}$ and at $1530 \mathrm{~h}$ throughout the experiment. The calves were allowed to drink for 15 minutes. Residual MR was subsequently collected and weighed. Except during the last week of adaptation, the SF was provided as a mixture (roughage and concentrates) directly after the MR meal, in a long feed through in front of the pen. Refusals of the SF were removed and weighed twice daily (i.e., just before the next MR meal). During the last 5 days of the adaptation period, the pair of calves was separated from the other calves of their pen, by placing a fence within the original pen. The pair of calves was subsequently accustomed to steady state feeding of the SF. During these 5 days, the SF was provided as a mixture in 4 equal portion per day (i.e., 0530, 0930, 1330, and 1730 h). Refusals of the SF were removed and weighed 4 times daily (i.e., just before the next SF meal).

\section{$2.4 \quad$ Breath Tests}

After the adaptation period, 4 pairs of calves ( 1 from each pen; 1 from each dietary treatment) were transported to 1 of 4 identical CRC, located approximately $200 \mathrm{~m}$ from the barn, for a 7-d period to determine the passage kinetics using the ${ }^{13} \mathrm{C}$ tracers in breath technique (Figure 1). Within each CRC (i.e., an area of $11.8 \mathrm{~m}^{2}$ and a volume of $\left.34.5 \mathrm{~m}^{3}\right), 1$ pair of calves was housed in a pen (225 x 240 $\mathrm{cm}$ ) equipped with a slatted, plastic flooring without bedding material. The calves were exposed to $10 \mathrm{~h}$ of light per day (from 0600 to $1800 \mathrm{~h}$ ) and the relative humidity was maintained at $65 \%$ and temperature at $18^{\circ} \mathrm{C}$.

\subsubsection{Feeding}

During the 7- $d$ measurement period in the CRC, calves were allowed ad libitum access to water provided via drinking nipples. The concentration of MR was $130 \mathrm{~g} / \mathrm{L}$ and was supplied individually in buckets at 40 to $42^{\circ} \mathrm{C}$, provided twice daily in equally sized meals at $0730 \mathrm{~h}$ and at $1530 \mathrm{~h}$ throughout the experiment. The calves were allowed to drink for 15 minutes. Residual MR was subsequently collected and weighed. The SF was provided as a mixture in 6 equal portion per day (i.e., 0000, 0400, 0800, 1200,1600 , and $2000 \mathrm{~h}$ ) to ensure steady state feeding. Steady state feeding was preferred in order to separate the ${ }^{13} \mathrm{C}$ enrichment as response from the ${ }^{13} \mathrm{C}$ tracer from the steady ${ }^{13} \mathrm{C}$ enrichment from the $\mathrm{SF}$. The administration of the ${ }^{13} \mathrm{C}$ tracer was at a different time than the MR meals were provided to distinguish between the ${ }^{13} \mathrm{C}$ enrichment as response to the ${ }^{13} \mathrm{C}$ tracer and the MR meals. Refusals of the SF were removed and weighed just before the morning MR meal. The natural ${ }^{13} \mathrm{C}$ enrichment of chopped straw and long hay were 1.074 atom\% and 1.076 atom\%, respectively, and the natural ${ }^{13} \mathrm{C}$ enrichment of the concentrate is assumed to be between that of the long hay and chopped straw (i.e., 1.075 atom\%), because of the ingredient composition.

\subsubsection{Measurements}

Passage kinetics was estimated using the recovery of ${ }^{13} \mathrm{C}$ tracers in breath measured in CRC. A detailed description of the CRC design and gas measurements is reported by Heetkamp et al. (2015) and van Gastelen et al. (2015). In addition, ${ }^{13} \mathrm{CO}_{2}$ production was measured every 12 min using nondispersive infrared spectrometry (Advance Optima Uras 14, ABB) as described by Alferink et al. (2003) in order to determine the passage kinetics of concentrates. The ${ }^{13} \mathrm{C}$ enrichment of the background breath measured in the CRC was $1.082 \pm 0.0009$ (mean \pm SD).

Figure 1 shows the order and time at which the ${ }^{13} \mathrm{C}$ tracers were administered. On $\mathrm{d} 2$ in the CRC, at 12.30h, bicarbonate sequestration was determined from expired ${ }^{13} \mathrm{CO}_{2}$ after injection of a bolus dose of $4.7 \mathrm{mmol}\left[{ }^{13} \mathrm{C}\right]$ sodium bicarbonate (99.1 atom\%; Mass Trace; Buchem B.V., Apeldoorn, the Netherlands) into an ear vein. The infusate was prepared in $10 \mathrm{~mL}$ sterile $0.15 \mathrm{~mol} / \mathrm{L} \mathrm{NaCl}$ and was injected within $2 \mathrm{~min}$ at $1300 \mathrm{~h}$, i.e. $1 \mathrm{~h}$ after a SF meal was provided. On d3 at $0800 \mathrm{~h}, 1 \mathrm{~g}$ [1- 
${ }^{13}$ C]octanoate (99.0 atom\%; Mass Trace; Buchem B.V., Apeldoorn, the Netherlands) was added to $1 / 6$ of the concentrate meal. Calves were allowed $240 \mathrm{~min}$ to consume the meal. The intake of the [1${ }^{13} \mathrm{C}$ ]octanoate concentrate meal was measured on an hourly basis. If present after 240 min, the residual of the $\left[1^{-13} \mathrm{C}\right]$ octanoate dosed concentrates was removed and the remainder of the SF meal was provided. In total, $84 \%$ of the calves consumed the pulse dose [1-13 C]octanoate within 240 min. Expired ${ }^{13} \mathrm{CO}_{2}$ was measured for $52 \mathrm{~h}$ after the pulse dose of $\left[1-{ }^{13} \mathrm{C}\right]$ octanoate. On d5 at $1600 \mathrm{~h}$, the complete concentrate part of the SF meal was replaced by a mixture containing $5.0 \%$ molasses, $46.7 \%$ barley, and $48.3 \%$ bacterial protein (Feedkind $\AA$, Calysta, partnered with Cargill, Wilton, United Kingdom) on DM basis. The bacterial protein was selected because it has a low natural ${ }^{13} \mathrm{C}$ enrichment (i.e., 1.057 atom\%) potentially resulting in a lower ${ }^{13} \mathrm{C}$ enrichment of the expired $\mathrm{CO}_{2}$. Again, the intake of the bacterial protein was measured on an hourly basis and the calves were allowed 240 min to consume the meal, after which it was removed. In total, $37 \%$ of the calves consumed the pulse dose of the bacterial protein within $240 \mathrm{~min}$. Expired ${ }^{13} \mathrm{CO}_{2}$ was measured for $64 \mathrm{~h}$ after the pulse dose of the bacterial protein.

\subsubsection{Calculations}

The ${ }^{13} \mathrm{CO}_{2}$ production from $\left[1-{ }^{13} \mathrm{C}\right]$ octanoate and the bacterial protein was calculated by multiplying $\mathrm{CO}_{2}$ production with ${ }^{13} \mathrm{C}$ enrichment in expired $\mathrm{CO}_{2}$ and corrected for background enrichment, as described by Gilbert et al. (2016). The area under the curve was integrated for calculating ${ }^{13} \mathrm{CO}_{2}$ production over a period for $48 \mathrm{~h}$ after isotope feeding. Oxidation of $\left[1-{ }^{13} \mathrm{C}\right]$ octanoate and the bacterial protein was expressed as percentage of the dose provided after correction for the number of C-atoms, chemical purity and isotope enrichment. Oxidation was corrected for an incomplete $\left[{ }^{13} \mathrm{C}\right]$ sodium bicarbonate recovery of $57.7 \pm 7.44 \%$, which is considerably lower that the values reported by van den Borne et al. (2007). For the pattern of ${ }^{13} \mathrm{CO}_{2}$ production in time, ${ }^{13} \mathrm{CO}_{2}$ production was averaged per $\mathrm{h}$ and expressed as a percentage of the dose provided.

The derivative of a generalized Michaelis-Menten equation, as proposed by López et al. (2000) for growth curves, was used to express ${ }^{13} \mathrm{CO}_{2}$ production in time (similar to van den Borne et al., 2007). The model was fitted to the hourly means of ${ }^{13} \mathrm{CO}_{2}$ excretion in breath (corrected for background enrichment) after ingestion of $\left[1-{ }^{13} \mathrm{C}\right]$ octanoate and the bacterial protein and after infusion of $\left[{ }^{13} \mathrm{C}\right]$ sodium bicarbonate:

$$
y=\frac{\left[b_{0} \times c \times(t-l t)^{(-c-1)} \times b_{1}{ }^{c}\right]}{\left[1+\left(\frac{b_{1}}{(t-l t)}\right)^{c}\right]^{2}}
$$

where $y={ }^{13} \mathrm{CO}_{2}$ production (micromoles per minute) at time $t$ (minutes); $I t=$ lagtime $(\min ) ; b_{0}, b_{1}$, and $c($ all $>0)$ are parameters that define the curve. The nonlinear least squares regression procedure (PROC NLIN, version 9.4, SAS Institute Inc., Cary, NC) was used for curve fitting. The time to peak $\left(\boldsymbol{t}_{\text {max }}\right)$ and the maximum ${ }^{13} \mathrm{CO}_{2}$ excretion (mmol/h, expressed as percentage of the dose), $\boldsymbol{y}_{\text {max }}$, were calculated as:

$$
\begin{gathered}
t_{\max }=l t+\left[b_{1}{ }^{c} \times(1-c) /(-c-1)\right]^{\left(\frac{1}{c}\right)}, \\
y_{\text {max }}=b_{0} \times c \times t_{\text {max }}{ }^{(-c-1)} \times b_{1}{ }^{c} /\left[1+\left(b_{1} / t_{\text {max }}\right)^{c}\right]^{2} .
\end{gathered}
$$

Goodness of fit for predicted against experimental data were assessed from the mean squared prediction error (MSPE) (Bibby and Toutenburg, 1977), calculated as:

$$
\operatorname{MSPE}=\sum_{i=1}^{n}\left(O_{i}-P_{i}\right)^{2} / n,
$$

where $n$ is the total number of observations, $O_{i}$ is the observed value and $P_{i}$ is the predicted value. The square root of the MSPE (RMSPE), expressed as percentage of the observed mean, gives an estimate of the overall prediction error. The RMSPE and means were calculated over time until $90 \%$ of the total recovery was achieved. Values beyond this point were close to baseline and contributed disproportionately to the mean. The RMSPE was decomposed into errors due to overall bias, errors due to deviation of the regression slope from unity, and errors due to random variation. The correlation between predicted and observed values was also calculated (Bibby and Toutenburg, 1977). 


\subsection{Fecal Excretion Curves}

After the 7- $d$ period in the CRC, the calves were transported back to the barn, where the calves were subsequently housed individually in pens of 1.5 by $3.0 \mathrm{~m}$ equipped with wooded-slatted floors) and fitted with harnesses to which plastic bags were attached for the quantitative collection of feces. Feces were collected at defined intervals for 4 days after oral administration of indigestible markers (Figure 1).

\subsubsection{Feeding}

During this measurement period for fecal excretion curves, calves were allowed ad libitum access to water provided via drinking nipples. The concentration of MR was $130 \mathrm{~g} / \mathrm{L}$ and was supplied individually in buckets at 40 to $42^{\circ} \mathrm{C}$, provided twice daily in equally sized meals at $0730 \mathrm{~h}$ and at $1530 \mathrm{~h}$ throughout the experiment. The calves were allowed to drink for 15 minutes. Residual MR was subsequently collected and weighed. The SF was provided as a mixture (roughage and concentrate) directly after the MR meal, in a long feed trough in front of the pen. Refusals of the SF were removed and weighed twice daily (i.e., just before the next MR meal).

\subsubsection{Measurements}

Indigestible markers were used to estimate passage kinetics of roughage, concentrates, and MR through the digestive tract of calves (Figure 1). The passage kinetics was assessed by measuring the recovery of external markers from fecal samples that were collected at defined intervals for 4 days (i.e., d11 to $\mathrm{d} 15$; every $3 \mathrm{~h}$ during the first 24 hours and every $4 \mathrm{~h}$ during the remaining $72 \mathrm{~h}$ ). Each marker was provided as a pulse dose and in a proportionate mixture with the other SF components corresponding to the treatment. To assess passage kinetics of roughage, chromium-mordanted (Cr-NDF) straw (i.e., for LowSF, MiddleSF, and HighSF treatments) and hay (i.e., for Hay treatment) were prepared as described by Udén et al. (1980). For the LowSF treatment, the total roughage part of the meal, which equals on average $39 \mathrm{~g} /$ calf, was replaced with Cr-NDF, whereas for the other treatments $60 \mathrm{~g} \mathrm{Cr}$ $\mathrm{NDF} /$ calf was provided. The $\mathrm{Cr}-\mathrm{NDF}$ was provided with the meal $24 \mathrm{~h}$ before the first fecal sample was collected (i.e., d10 at $0730 \mathrm{~h}$ ). In total, 75\% of the calves consumed the pulse dose with $\mathrm{Cr}-\mathrm{NDF}$ within $120 \mathrm{~min}$. To assess passage kinetics of concentrates, $2 \mathrm{~g}$ of Ytterbium(II)Oxide $\left(\mathbf{Y b}_{\mathbf{2}} \mathbf{O}_{\mathbf{3}}\right)$ was mixed with $1 / 6$ of the concentrate meal $14 \mathrm{~h}$ before the first fecal sample was collected (i.e., d10 at $1530 \mathrm{~h}$ ). Calves were allowed 120 min to consume the meal, after which the remainder of the SF meal was provided. In total, $90 \%$ of the calves consumed the pulse dose with $\mathrm{Yb}_{2} \mathrm{O}_{3}$ within $120 \mathrm{~min}$. To assess passage kinetics of MR, $9 \mathrm{~g}$ of cobalt(II)EDTA (co-EDTA; Udén et al., 1980) was dissolved into the last MR meal just before the collection of the fecal samples started (i.e., d11 at $0730 \mathrm{~h}$ ). Calves were allowed 15 min to consume the meal and all calves consumed the pulse dose with co-EDTA within 15 min.

\subsubsection{Calculations}

The recovery of the indigestible markers $\mathrm{Co}, \mathrm{Yb}$, and $\mathrm{Cr}$ was calculated by measuring the recovery of the markers of each fecal sample separately as \% of dose administered. Subsequently, the cumulative recovery per calf was calculated.

The calculations described above for ${ }^{13} \mathrm{CO}_{2}$ production, were also applied to the fecal concentrations of the ingestible markers. We worked with the concentrations of $\mathrm{Co}, \mathrm{Yb}$, and $\mathrm{Cr}$ on a $\mathrm{g} / \mathrm{kg} \mathrm{ADM}$ feces basis, not with recoveries or with excretions. The generalized Michaelis-Menten equation, as proposed by López et al. (2000), was used to express fecal concentrations of the indigestible markers in time with the $y$ variable being the fecal concentrations of indigestible markers at time $t$ (minutes). Also $\boldsymbol{y}_{\max }$ was calculated, representing the maximum indigestible marker concentration ( $\mathrm{g} / \mathrm{kg}$ ADM feces).

In addition, a multicompartmental model to describe the indigestible marker concentration patterns in the feces was applied. The fecal marker excretion technique is based on the fact that the pattern of marker excretion in the feces after an oral pulse dose on the marker reflects the cumulative effect of marker residence time in the various compartments of the digestive tract. Provided a satisfactory mathematical description of the excretion curve can be achieved and the components parts identified, 
the mean retention time (MRT) in the rumen can be obtained (Dhanoa et al., 1985). Therefore, the fecal excretion patterns of the markers following an oral pulse dose (i.e., into the rumen) were fit to a nonlinear multicompartmental model as proposed by Dhanoa et al., (1985) and applied by Pellikaan et al. (2004):

$$
Y t=A e^{-\left(K_{1} \times t\right)} \exp \left[-(N-2) e^{-\left(K_{2}-K_{1}\right) \times t}\right]
$$

Where $Y t$ represents the fecal marker concentration ( $\mathrm{g} / \mathrm{kg}$ ADM feces) at time $=t, N$ denotes the number of compartments, $K_{1}$ and $K_{2}$ resemble the fractional rate constants for the 2 compartments in the digestive tract with the longest retention times and $A$ forms a scalable parameter dependent on the $N$, $K_{1}$, and $K_{2}$. The curve fitting was done using the nonlinear least squares regression procedure PROC NLIN (version 9.4, SAS Institute Inc., Cary, NC).

From the parameter estimates on the basis of the multicompartmental model, the transit time (TT; the moment of first appearance of the marker in the feces), the mean retention time of slowest compartment (CMRT1), the mean retention time of the second slowest compartment (CMRT2), the total mean retention time (TMRT), and the moment of peak concentration (PCT; resembles the moment when excretion curve reaches peak concentration) were calculated:

$$
\begin{gathered}
T T(\text { in } h)=\sum_{i=3}^{N-1} \frac{1}{K_{2}}+(i-2) \times\left(K_{2}-K_{1}\right) \\
C M R T 1=\frac{1}{K_{1}}, C M R T 2=\frac{1}{K_{2}} \\
T M R T(\text { in } h)=\frac{1}{K_{1}}+\frac{1}{K_{2}}+\sum_{i=3}^{N-1} \frac{1}{K_{2}}+(i-2) \times\left(K_{2}-K_{1}\right) \\
P C T(\text { in } h)=\frac{\ln \left[(N-2) \times \frac{K_{2}+K_{1}}{K_{2}}\right]}{K_{2}-K_{1}}
\end{gathered}
$$

\subsection{Chemical Analyses}

Samples of $\mathrm{MR}$, concentrates, straw, and hay were collected weekly, pooled over the experimental period, and stored at $-20^{\circ} \mathrm{C}$ pending analysis. Also, the fecal samples collected after oral administration of indigestible markers were stored directly at $-20^{\circ} \mathrm{C}$ pending analysis. Samples of the feed components and feces were thawed at room temperature, oven-dried at $60^{\circ} \mathrm{C}$, ground to pass a $1-\mathrm{mm}$ screen using a cross beater mill (Peppink 100AN, Olst, the Netherlands), and subsequently analyzed. The feed components were analyzed for DM, N, gross energy (GE), and phosphorus, whereas the fecal samples and $\mathrm{Cr}$ mordants were analyzed for DM, and concentrations of $\mathrm{Cr}$ (from $\mathrm{Cr}-\mathrm{NDF}$ ), $\mathrm{Yb}$ (from $\mathrm{Yb}_{2} \mathrm{O}_{3}$ ), and Co (from co-EDTA).

Dry matter content was determined by drying to a constant weight according to ISO 6496 (ISO, 1998). Bomb calorimetry (ISO 9831; International Organization for Standardization, 1998) was used to determine GE. Crude protein was calculated as $\mathrm{N} \times 6.25$, where $\mathrm{N}$ was determined using the Dumas principle (ISO 16634-1; International Organization for Standardization, 2008). The phosphorus content was determined by incinerating a test portion at $550^{\circ} \mathrm{C}$ and digesting with concentrated hydrochloric acid. Molybdovanadate reagent was added, resulting in a characteristic yellow color after reacting with phosphorus, which was subsequently measured spectrophotometrically at $430 \mathrm{~nm}$ (ISO 6491; International Organization for Standardization, 1998).

The DM, ash, and calcium content of the MR and concentrates were determined by Denkavit Nederland B.V. (Voorthuizen, the Netherlands). Dry matter content was determined by drying to a constant weight according to ISO 6496 (ISO, 1998). Ash content was determined according to ISO 5984 (ISO, 2003) and calcium content was determined according to ISO 15510 (ISO, 2017). The Cr, Co, and Yb concentrations in the feces samples were determined by NutriControl (Veghel, the Netherlands) using inductive coupled plasma - optical emission spectrometry (ICP-OES) after wet-destruction. 


\subsection{Statistical Analyses}

The dataset for the indigestible marker part of this study contained 39 observations (i.e., 39 individual calf observations), whereas the dataset for the ${ }^{13} \mathrm{C}$ tracer part of this study contained 20 observations (i.e., 20 observations of pair-housed calves in the CRC). Due to health problems not related to the dietary treatments or experimental conditions (e.g., lung infections), 2 calves were excluded from the trial. Additionally, 1 calf appeared to be ruminal drinker, and was excluded from the trial. Furthermore, 2 calves, who formed a pair in the CRC, were excluded from the ${ }^{13} \mathrm{C}$ tracer part of this study, because their MR refusals exceeding $10 \%$ of the MR provided while housed in the CRC. Also, due to a fire in the oven upon drying the fecal samples, almost all samples from the third group of the first batch of calves were lost. As a result, 6 calves of the first batch could not be used for data analyses.

Dependent variables were analyzed by mixed model analysis in PROC MIXED (SAS 9.4, SAS Institute Inc., Cary, NC) for continuous data, with calf as experimental unit for the indigestible marker part of the study and the pair of calves housed in the CRC as experimental unit for the ${ }^{13} \mathrm{C}$ tracer part of the study. Dietary treatment (i.e., LowSF, MiddleSF, HighSF, and Hay), batch (i.e., 1 and 2), and group within batch (i.e., 1, 2, and 3) were fixed effects. The covariance structure compound symmetry provided best fit with the lowest overall Akaike's information criterion values and the Kenward-Roger option was used to estimate the denominator degrees of freedom. Differences between treatment means were compared using the least square means procedure and the Tukey-Kramer method for multiple comparisons when a treatment effect was detected at $P \leq 0.05$. All results are presented as least squared means and their standard error of the mean with significance of effects declared at $P \leq 0.05$ and trends at $0.05<P \leq 0.10$. 


\section{Results}

\subsection{Animal Performance}

Animal performance and the energy balance of the calves in the CRC for the measurement of ${ }^{13} \mathrm{C}$ in breath has been reported by Mens et al. (to be submitted) and was similar to the animal performance of the calves during the indigestible marker part of this study (Table 3). The DMI of MR, concentrates, and roughages as well as total DMI are consistent with the experimental design, and have not been statistically evaluated. Consistent with the paired-gain feeding strategy, no differences where observed in body weight or ADG. Also, differences in feed conversion ratio between the treatments did not reach statistical significance.

\subsection{Recovery of ${ }^{13} \mathrm{C}$ Tracers in Breath}

The time to peak $(\mathrm{h})$ of $\left[1-{ }^{13} \mathrm{C}\right]$ octanoate, corrected for $\left[{ }^{13} \mathrm{C}\right]$ sodium bicarbonate, ranged from $1.93 \mathrm{~h}$ to $2.57 \mathrm{~h}$, and was not affected by the dietary treatments ( $P=0.912$; Table 4, Figure 2$)$. The RMSPE of the curve fits for ${ }^{13} \mathrm{CO}_{2}$ production from $\left[1{ }^{13} \mathrm{C}\right]$ octanoate averaged $19.4 \%\left(R^{2}=0.84\right)$, with the majority of the prediction error $(92.6 \%)$ attributable to random variation. The time to peak $(\mathrm{h})$ of $\left[{ }^{13} \mathrm{C}\right]$ sodium bicarbonate, ranged from $1.16 \mathrm{~h}$ to $1.40 \mathrm{~h}$, and was also not affected by the dietary treatments $(P=$ $0.463)$. The RMSPE of the curve fits for ${ }^{13} \mathrm{CO}_{2}$ production from $\left[{ }^{13} \mathrm{C}\right]$ sodium bicarbonate averaged $11.8 \%$ $\left(R^{2}=0.98\right)$, with the majority of the prediction error $(87.6 \%)$ attributable to random variation.

Both the recovery of $\left[{ }^{13} \mathrm{C}\right]$ sodium bicarbonate and $\left[1-{ }^{13} \mathrm{C}\right]$ octanoate as ${ }^{13} \mathrm{CO}_{2}$ (the latter corrected and not corrected for $\left[{ }^{13} \mathrm{C}\right]$ sodium bicarbonate) were not affected by dietary treatments $(P>0.159)$. The maximum ${ }^{13} \mathrm{CO}_{2}$ production (\% of dose / h) of $\left[1-{ }^{13} \mathrm{C}\right]$ octanoate (corrected and not corrected for $\left[{ }^{13} \mathrm{C}\right]$ sodium bicarbonate) was also not affected by the dietary treatments $(P>0.589)$, whereas the maximum ${ }^{13} \mathrm{CO}_{2}$ production ( $\%$ of dose $/ \mathrm{h}$ ) tended to be affected by the dietary treatments $(P=0.071)$.

Despite the fact that the bacterial protein had a considerably lower ${ }^{13} \mathrm{C}$ enrichment relative to the background breath (1.057 vs. 1.070 atom\%, respectively), we were not able to measure any response in ${ }^{13} \mathrm{CO}_{2}$ production after the oral dose of bacterial protein.

\subsection{Fecal Excretion Curves of Ingestible Markers}

\subsubsection{Milk Replacer}

The time to peak (h) of Co was 13.3, 13.3, 12.0, and 10.9 for LowSF, MiddleSF, HighSF, and Hay, respectively, and tended to be affected by the dietary treatment $(P=0.071$; Table 5$)$. The RMSPE of the curve fits for fecal Co from orally dosed co-EDTA averaged $36.4 \%\left(R^{2}=0.95\right)$, with the majority of the prediction error (84.6\%) attributable to random variation. The maximum excretion of Co ( $g / \mathrm{kg}$ ADM feces) ranged from 9.52 to $12.5 \mathrm{~g} / \mathrm{kg}$ ADM feces and the recovery (\% of Co intake) ranged from 101.1 to $113.4 \%$ of intake. The maximum excretion of Co as well as the recovery of Co tended to be affected by the dietary treatments ( $P=0.054$ and $P=0.065$, respectively), with both being numerically lower for the Hay treatment (Table 5; Figure 3 upper panel).

\subsubsection{Concentrates}

The time to peak of $\mathrm{Yb}$ ranged from 19.5 to $22.5 \mathrm{~h}$ and was not affected by dietary treatment $(P=0.420$, Table 5). The RMSPE of the curve fits for fecal $\mathrm{Yb}$ from orally dosed $\mathrm{Yb}_{2} \mathrm{O}_{3}$ averaged $18.6 \%\left(\mathrm{R}^{2}=0.81\right)$, with the majority of the prediction error $(89.7 \%)$ attributable to random variation. The lagtime ( $h$; time of first appearance of $\mathrm{Yb}_{2} \mathrm{O}_{3}$ in the feces), being either 16.0h for the LowSF and MiddleSF treatment or 15.9h for the HighSF and Hay treatment, was not affected by dietary treatment $(P=0.481)$. 
Also the recovery ( $\%$ of $\mathrm{Yb}_{2} \mathrm{O}_{3}$ intake), which ranged between 68.9 and $82 \%$, was not affected by dietary treatment $(P=0.243)$. The maximum excretion of $\mathrm{Yb}(\mathrm{g} / \mathrm{kg}$ ADM feces) was higher $(P<0.001)$ for both LowSF and MiddleSF (1.93 and $1.87 \mathrm{~g} / \mathrm{kg}$ ADM feces, respectively) compared with both HighSF and Hay ( 1.17 and $1.35 \mathrm{~g} / \mathrm{kg}$ ADM feces, respectively; Table 5, Figure 3 middle panel).

\subsubsection{Roughage}

The time to peak $(\mathrm{h})$ of $\mathrm{Cr}$ was lower $(P=0.004 ; 36.8 \mathrm{~h})$ for the Hay treatment compared with both LowSF and MiddleSF (64.3 and 59.5h, respectively; Table 5). The RMSPE of the curve fits for fecal $\mathrm{Cr}$ from orally dosed Cr-NDF averaged $22.0 \%\left(R^{2}=0.66\right)$, with the majority of the prediction error $(82.5 \%)$ attributable to random variation. Also the recovery of $\mathrm{Cr}$ (\% of $\mathrm{Cr}$ intake) was higher $(P=0.009$; $100.1 \%)$ for the Hay treatment compared with the other 3 straw containing treatments LowSF, MiddleSF, and HighSF (69.6, 69.3, and 71.4\%, respectively; Table 5, Figure 3 lower panel). The lagtime ( $h$; time of first appearance of $\mathrm{Cr}$ in the feces), ranging from 23.6 to $23.9 \mathrm{~h}$, as well as the maximum excretion of $\mathrm{Cr}$ ( $\mathrm{g} / \mathrm{kg}$ ADM feces), ranging from 0.82 to $1.10 \mathrm{~g} / \mathrm{kg}$ ADM feces, were not affected by dietary treatment $(P>0.115)$. 
Figure 1. Timeline of the experimental protocol per batch of calves (2 batches, 24 calves each). For each treatment ( 6 calves per treatment), the adaptation period ranged from 6 to 9 weeks for pair 1 to 3 (i.e., paired according to BW). The second batch of calves had a higher BW from the start, therefore having a shorter adaptation period ranging from 5 to 8 weeks. The adaptation period was followed by 7 days in climate respiration chambers (pairhoused) to measure the recovery of ${ }^{13} \mathrm{C}$ tracers in breath after intravenous administration of $\left[{ }^{13} \mathrm{C}\right]$ sodium bicarbonate and oral administration of $\left[1-{ }^{13} \mathrm{C}\right]$ octanoate and the bacterial protein. Subsequently, calves were fitted with harnesses to which plastic bags were attached and housed individually in a pen for 7 days, to determine the fecal excretion curves of 3 orally administrated indigestible markers (i.e., $\mathrm{Cr}-\mathrm{NDF}, \mathrm{Yb}_{2} \mathrm{O}_{3}$, and co-EDTA).

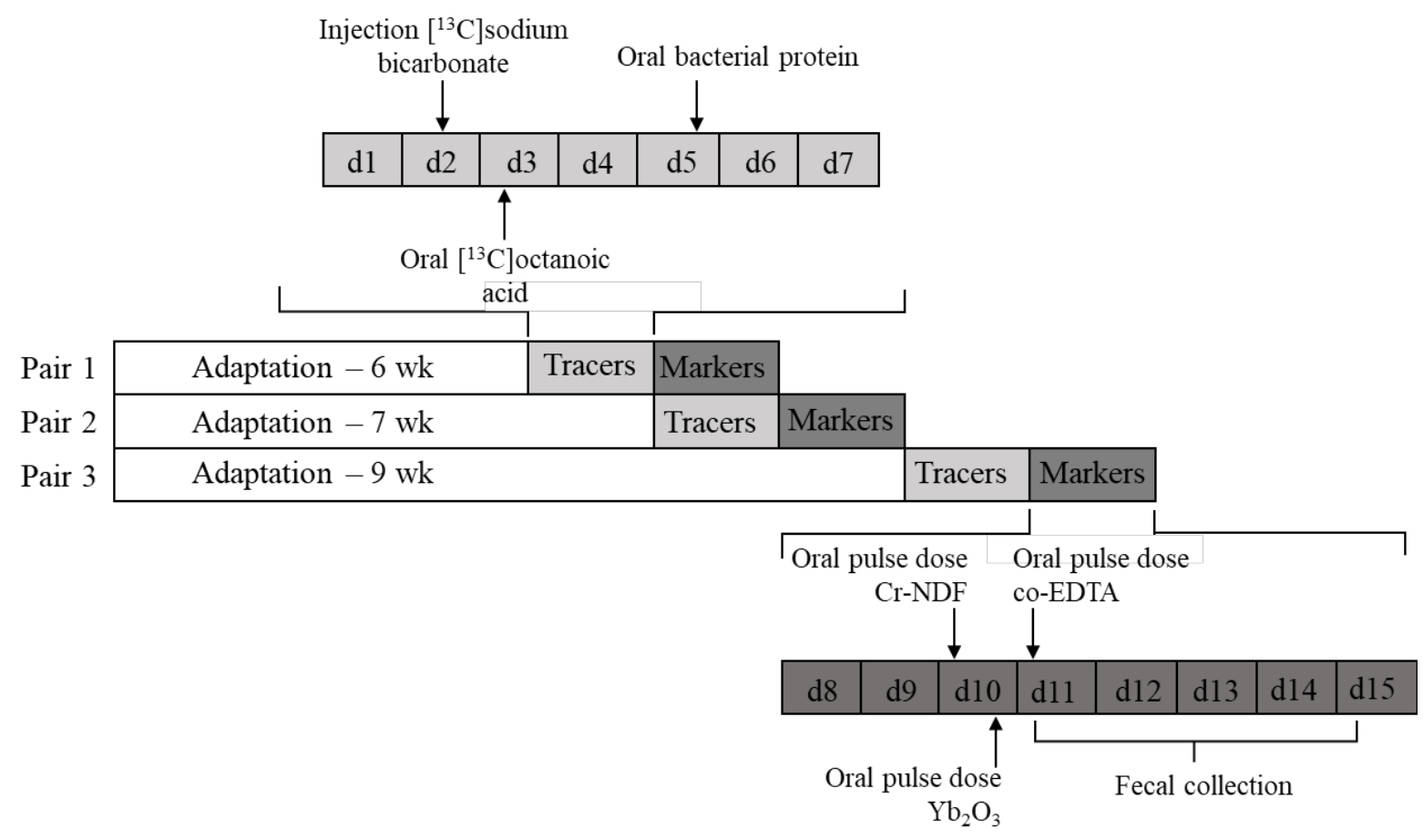


Figure 2. Production of ${ }^{13} \mathrm{CO}_{2}$ after a pulse dose of $\left[{ }^{13} \mathrm{C}\right]$ sodium bicarbonate was injected into the ear vein (upper panel) and after feeding a single dose of $\left[1{ }^{13} \mathrm{C}\right]$ octanoate (lower panel). The curves are based on the model of van der Borne et al. (2007), using the parameter estimates averaged per treatment, uncorrected for $\left[{ }^{13} \mathrm{C}\right]$ sodium bicarbonate.
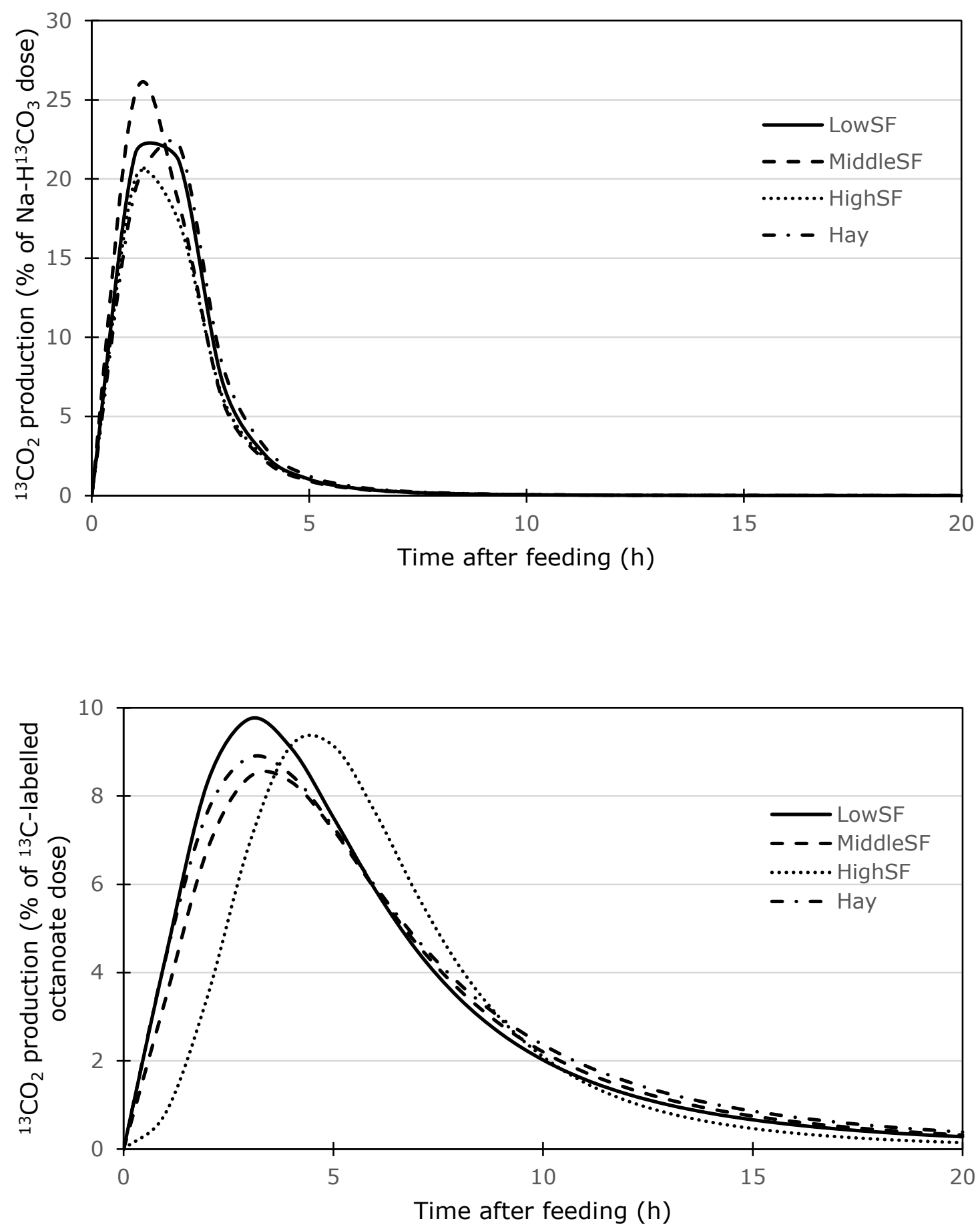
Figure 3. Excretion curves of Co (upper panel), Yb (middle panel), and Cr (lower panel; next page). Cobalt was pulse-dosed as Co-EDTA with milk replacer directly before sampling feces; $Y b$ was pulse-dosed as $\mathrm{Yb}_{2} \mathrm{O}_{3}$ with the concentrates at $16 \mathrm{~h}$ before sampling; $\mathrm{Cr}$ was pulsedosed as Cr-NDF with chopped straw (for treatments LowSF, MiddleSF, and HighSF) or long hay (for treatment Hay) $48 \mathrm{~h}$ before sampling. The excretion curves are based on the model of van der Borne et al. (2007), using the parameter estimates averaged per treatment.
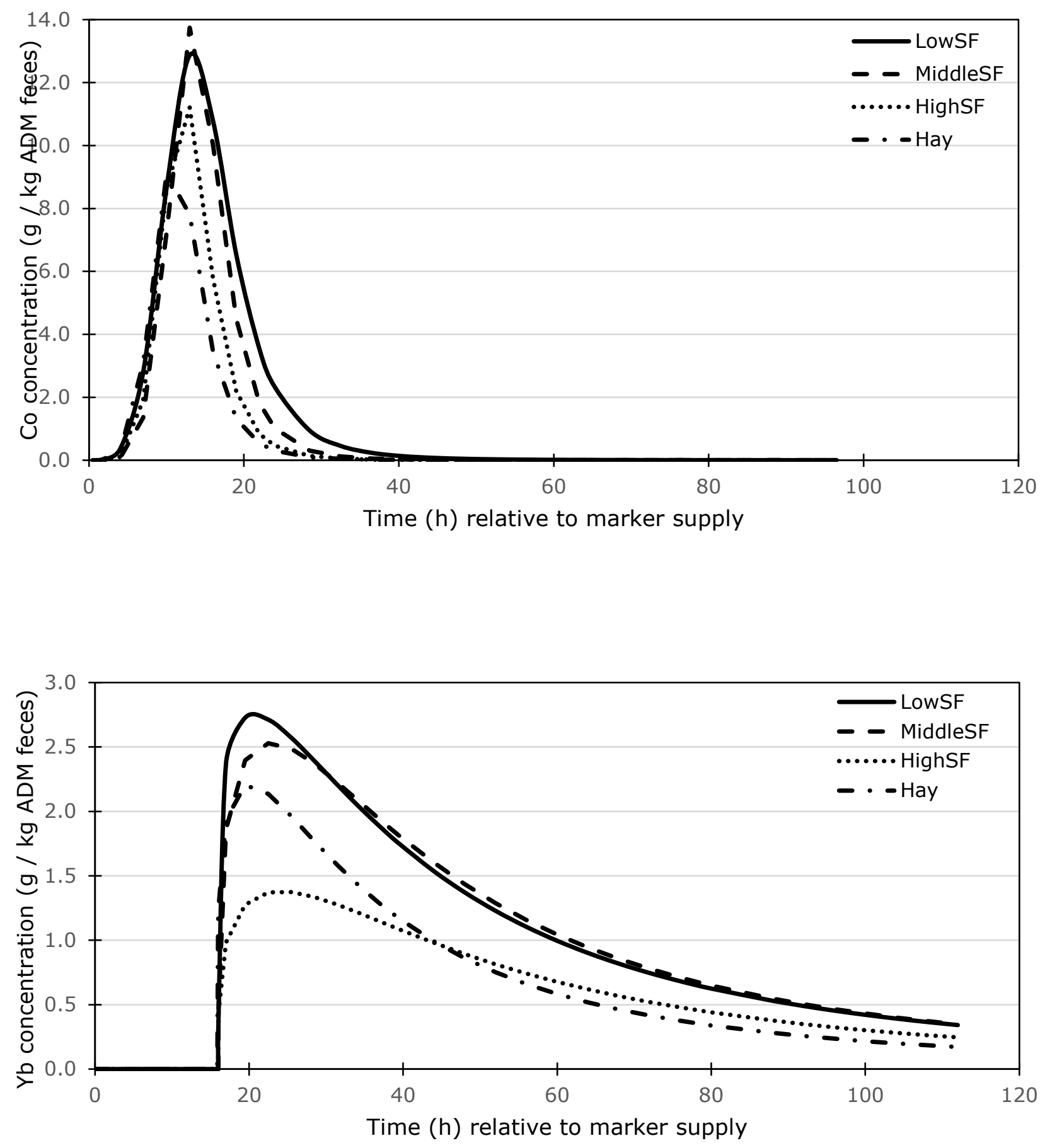


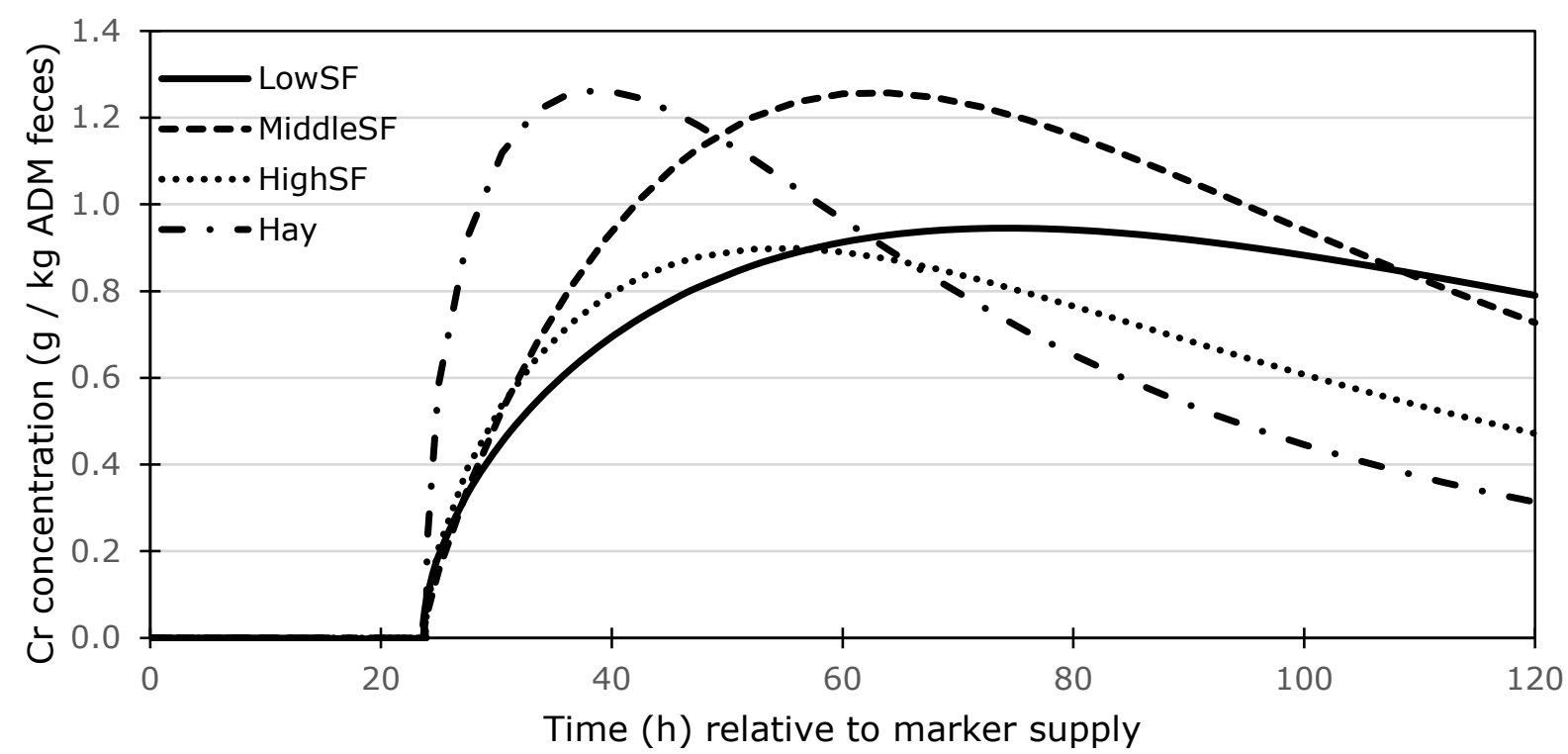


Table 1. Paired gain feeding schedule of the different diets.

\begin{tabular}{|c|c|c|c|c|c|c|}
\hline Treatment & $\begin{array}{c}\mathrm{MR}^{1} \\
(\mathrm{~g} / \mathrm{kg} \\
\left.\mathrm{BW}^{0.75} / \mathrm{d}\right)\end{array}$ & $\begin{array}{c}\mathrm{SF}^{2} \\
(\mathrm{~g} / \mathrm{kg} \\
\left.\mathrm{BW}^{0.75} / \mathrm{d}\right)\end{array}$ & $\begin{array}{c}\text { Concentrates } \\
\qquad(\mathrm{g} / \mathrm{kg} \\
\left.\mathrm{BW}^{0.75} / \mathrm{d}\right)\end{array}$ & $\begin{array}{l}\text { Roughage } \\
\qquad(\mathrm{g} / \mathrm{kg} \\
\left.\mathrm{BW}^{0.75} / \mathrm{d}\right)\end{array}$ & $\begin{array}{c}\text { Concentrate } \\
\text { to roughage } \\
\text { ratio }\end{array}$ & $\begin{array}{c}\text { Roughage } \\
\text { type }\end{array}$ \\
\hline LowSF & 50.6 & 20 & 18 & 2 & $90: 10$ & Chopped straw \\
\hline MiddleSF & 44.8 & 30 & 27 & 3 & $90: 10$ & Chopped straw \\
\hline HighSF & 39.0 & 40 & 36 & 4 & $90: 10$ & Chopped straw \\
\hline Hay & 41.4 & 40 & 28 & 12 & $70: 30$ & Long hay \\
\hline
\end{tabular}

${ }^{1}$ Milk replacer mixed with water in a concentration of $130 \mathrm{~g} / \mathrm{L}$. The amount of MR for the HighSF treatment was fixed. The amount of MR for the other treatments was based on pair gain strategy during the adaptation period, after which it was fixed as well.

2 Solid feed.

Table 2. Nutrient and chemical composition of milk replacer (MR), concentrates and roughages in $\mathrm{g} / \mathrm{kg} D \mathrm{M}$, unless stated otherwise.

\begin{tabular}{lccccc} 
& & \multicolumn{2}{c}{ Concentrates } & \multicolumn{2}{c}{ Roughages } \\
\cline { 5 - 7 } Nutrient $^{1}$ & MR $^{2}$ & C_Straw & C_Hay & Chopped straw Long hay \\
Dry matter (g/kg product) & 968 & 885 & 900 & 936 & 903 \\
\hline Organic matter & 940 & 953 & 953 & n.d. ${ }^{5}$ & n.d. \\
\hline Crude protein & 184 & 168 & 181 & 41 & 101 \\
\hline Crude fat & 212 & 52 & 48 & n.d. & n.d. \\
\hline Gross energy (MJ/kg DM) & 21.1 & 18.7 & 18.6 & 18.9 & 18.7 \\
\hline Calcium & 8.00 & 6.40 & 6.40 & n.d. & n.d. \\
\hline Phosphorus & 6.56 & 4.62 & 4.93 & 0.39 & 2.55 \\
\hline
\end{tabular}

${ }^{1}$ Presented as $\mathrm{g} / \mathrm{kg}$ dry matter, unless stated otherwise.

2 Ingredient composition of MR: 38\% lactose, 21\% fatfilled wheypowder (i.e., $80 \%$ palm and $20 \%$ coconut), $20 \%$ whey protein concentrate, $10 \%$ vegetable oil (i.e., $70 \%$ palm, $20 \%$ coconut, and $10 \%$ rapeseed), 7\% wheypowder, and 4\% mineral premix (i.e., Vitamin A, 25,000 IU; Vitamin $D_{3}, 4,000 \mathrm{IU}$; Vitamin $E, 100$ mg; Vitamin $K_{3}, 2.0$ mg; Vitamin $B_{1}, 5.0$ mg; Vitamin $B_{2}, 7.5$ mg; Vitamin $B_{3}, 40$ mg; Vitamin $B_{5}, 20$ mg; Vitamin $B_{6}, 5.0$ mg; Vitamin $B_{12}, 40$ mcg; Biotin, 125 mcg; Choline, $350 \mathrm{mg}$ ).

${ }^{3}$ Ingredient composition of concentrates fed with straw-based diets LowSF, MiddleSF, and HighSF: 55\% corn, 37\% lupins, 5\% barley, and 3\% mineral premix (i.e., Magnesium, $1 \mathrm{~g}$; Vitamin A, 4,000 IU; Vitamin $D_{3}, 5,000 \mathrm{IU}$; Vitamin E, $50 \mathrm{mg}$; Vitamin $\mathrm{B}_{1}, 2.0 \mathrm{mg}$; Vitamin $\mathrm{B}_{2}, 2.5 \mathrm{mg}$; Vitamin $\mathrm{B}_{6}, 2.0 \mathrm{mg}$; Manganese, $20 \mathrm{mg}$; Copper, $10 \mathrm{mg}$; Zinc, $25 \mathrm{mg}$; Potassium iodide, $0.80 \mathrm{mg}$; Cobalt, $0.10 \mathrm{mg}$; Selenium, $0.15 \mathrm{mg}$ ).

${ }^{4}$ Ingredient composition of concentrates fed with the hay-based diet Hay: 44\% lupins, $22 \%$ maize feed flour, 26\% corn, 5\% barley, and 3\% mineral premix (i.e., Magnesium, $1 \mathrm{~g}$; Vitamin A, 4,000 IU; Vitamin $\mathrm{D}_{3}, 5,000 \mathrm{IU}$; Vitamin $\mathrm{E}, 50 \mathrm{mg}$; Vitamin $\mathrm{B}_{1}, 2.0 \mathrm{mg}$; Vitamin $\mathrm{B}_{2}, 2.5 \mathrm{mg}$; Vitamin $\mathrm{B}_{6}, 2.0 \mathrm{mg}$; Manganese, $20 \mathrm{mg}$; Copper, $10 \mathrm{mg}$; Zinc, $25 \mathrm{mg}$; Potassium iodide, $0.80 \mathrm{mg}$; Cobalt, $0.10 \mathrm{mg}$; Selenium, $0.15 \mathrm{mg}$ ).

${ }^{5}$ Not determined. 
Table 3. The effect of different levels of solid feed (20,30, 40 and $40 \mathrm{~g} / \mathrm{kg} \mathrm{BW}$. $75 / \mathrm{d}$ for LowSF, MiddleSF, HighSF, and Hay, respectively) and type of roughage (chopped straw for LowSF, MiddleSF, and HighSF, and long hay for Hay) on calf performance during the fecal excretion study.

\begin{tabular}{|c|c|c|c|c|c|c|}
\hline \multirow[b]{2}{*}{ Item } & \multicolumn{4}{|c|}{ Treatment } & \multirow[b]{2}{*}{ SEM } & \multirow[b]{2}{*}{$P$-value } \\
\hline & LowSF & MiddleSF & HighSF & Hay & & \\
\hline No. of animals & 9 & 10 & 10 & 10 & n.a. & n.a. \\
\hline Body weight (kg) & 134.7 & 138.8 & 135.7 & 137.7 & 2.18 & 0.686 \\
\hline DMI $^{1}$ milk replacer $(\mathrm{kg} / \mathrm{d})$ & 1.94 & 1.75 & 1.51 & 1.60 & 0.021 & n.d. ${ }^{2}$ \\
\hline DMI roughages $(\mathrm{kg} / \mathrm{d})$ & 0.07 & 0.11 & 0.13 & 0.39 & 0.009 & n.d. ${ }^{2}$ \\
\hline DMI concentrates $(\mathrm{kg} / \mathrm{d})$ & 0.60 & 0.89 & 1.07 & 0.91 & 0.039 & n.d. ${ }^{2}$ \\
\hline DMI total $(\mathrm{kg} / \mathrm{d})$ & 2.60 & 2.74 & 2.70 & 2.91 & 0.052 & n.d. ${ }^{2}$ \\
\hline Average daily gain $(\mathrm{kg} / \mathrm{d})$ & 1.44 & 1.52 & 1.21 & 1.29 & 0.119 & 0.261 \\
\hline Feed conversion ratio ${ }^{3}$ & 1.83 & 1.88 & 2.91 & 2.59 & 0.420 & 0.275 \\
\hline
\end{tabular}

1 Dry matter intake.

2 Not determined; differences in DMI milk replacer, DMI roughages, and DMI concentrates between treatments is due to the design of the treatments.

${ }^{3}$ Ratio between DMI total $(\mathrm{kg} / \mathrm{d})$ and average daily gain $(\mathrm{kg} / \mathrm{d})$.

Table 4. The effect of different levels of solid feed (20,30, 40 and $40 \mathrm{~g} / \mathrm{kg} \mathrm{BW} 0.75 / \mathrm{d}$ for LowSF, MiddleSF, HighSF, and Hay, respectively) and type of roughage (chopped straw for LowSF, MiddleSF, and HighSF, and long hay for Hay) on the time to peak (h), maximum rate of ${ }^{13} \mathrm{CO}_{2}$ production, and isotope recovery as ${ }^{13} \mathrm{CO}_{2}$ after a pulse dose $\left[{ }^{13} \mathrm{C}\right]$ sodium bicarbonate was injected into the ear vein (upper panel) and after feeding a single dose of $\left[1-{ }^{13} \mathrm{C}\right]$ octanoate.

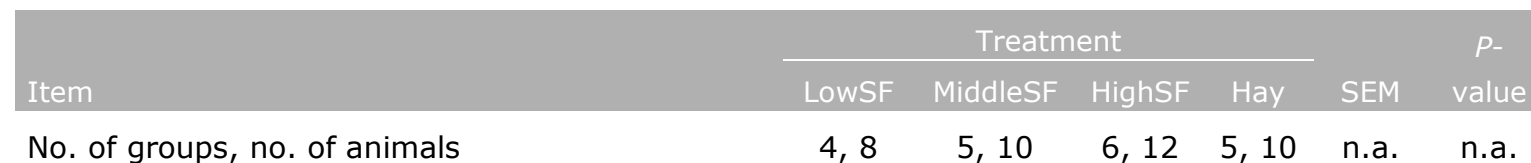

$\left[{ }^{13} \mathrm{C}\right]$ sodium bicarbonate

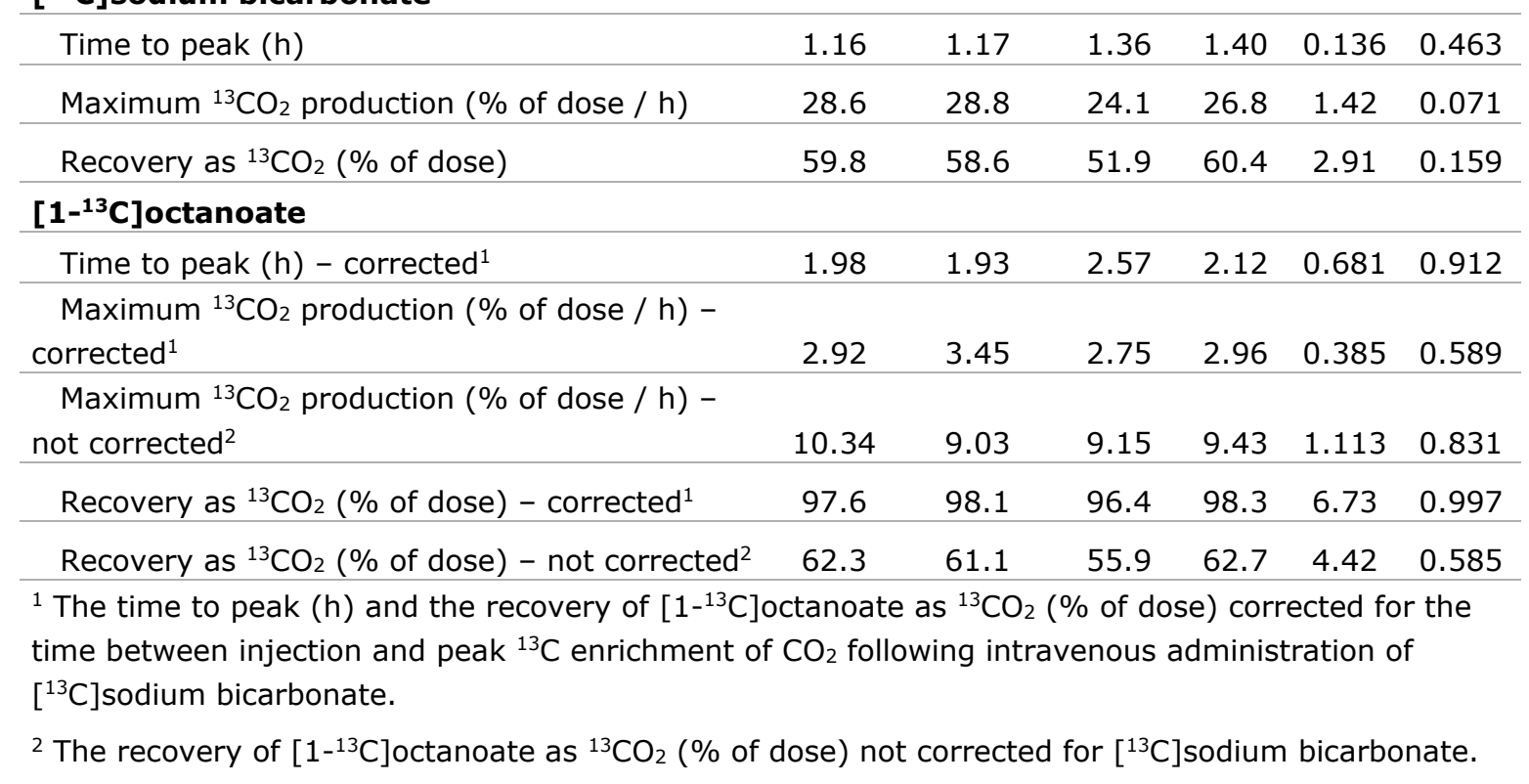


Table 5. The effect of different levels of solid feed (20,30, 40 and $40 \mathrm{~g} / \mathrm{kg} \mathrm{BW} 0.75 / \mathrm{d}$ for LowSF, MiddleSF, HighSF, and Hay, respectively) and type of roughage (chopped straw for LowSF, MiddleSF, and HighSF, and long hay for Hay) on the excretion and recovery of pulse-dosed markers $\mathrm{Co}, \mathrm{Cr}$, and $\mathrm{Yb}$ in the feces of veal calves.

\begin{tabular}{|c|c|c|c|c|c|c|}
\hline \multirow[b]{2}{*}{ Item } & \multicolumn{4}{|c|}{ Treatment } & \multirow[b]{2}{*}{ SEM } & \multirow[b]{2}{*}{ P-value } \\
\hline & LowSF & MiddleSF & HighSF & Hay & & \\
\hline No. of animals & 9 & 10 & 10 & 10 & n.a. & n.a. \\
\hline \multicolumn{7}{|l|}{ Milk replacer ${ }^{1}$} \\
\hline Time to peak $(\mathrm{h})$ & 13.3 & 13.3 & 12.0 & 10.9 & 0.63 & 0.071 \\
\hline $\begin{array}{l}\text { Maximum excretion ( } \mathrm{g} / \mathrm{kg} \text { ADM } \\
\text { feces) }\end{array}$ & 12.50 & 13.63 & 11.26 & 9.52 & 0.925 & 0.054 \\
\hline Recovery (\% of intake) & 113.4 & 108.9 & 108.1 & 101.1 & 2.80 & 0.065 \\
\hline \multicolumn{7}{|l|}{ Concentrates $^{2}$} \\
\hline Lagtime (h) & 16.0 & 16.0 & 15.9 & 15.9 & 0.05 & 0.481 \\
\hline $\begin{array}{l}\text { Time to peak ( } h \text {; including } \\
\text { labtime) }\end{array}$ & 21.0 & 22.4 & 22.5 & 19.5 & 1.33 & 0.420 \\
\hline $\begin{array}{l}\text { Maximum concentration }(\mathrm{g} / \mathrm{kg} \\
\text { ADM feces) }\end{array}$ & $1.93^{\mathrm{a}}$ & $1.87^{a}$ & $1.17^{b}$ & $1.35^{\mathrm{b}}$ & 0.122 & $<0.001$ \\
\hline Recovery (\% of intake) & 82.0 & 81.1 & 68.9 & 80.2 & 4.57 & 0.243 \\
\hline \multicolumn{7}{|l|}{ Roughage $^{3}$} \\
\hline Lagtime (h) & 23.6 & 23.6 & 23.8 & 23.9 & 0.2321 & 0.811 \\
\hline $\begin{array}{l}\text { Time to peak ( } h \text {; including } \\
\text { labtime) }\end{array}$ & $64.3^{\mathrm{a}}$ & $59.5^{a}$ & $53.4^{\mathrm{ab}}$ & $36.8^{b}$ & 4.55 & 0.004 \\
\hline $\begin{array}{l}\text { Maximum concentration }(\mathrm{g} / \mathrm{kg} \\
\text { ADM feces) }\end{array}$ & 0.92 & 1.10 & 0.82 & 0.93 & 0.071 & 0.115 \\
\hline Recovery (\% of intake) & $69.6^{a}$ & $69.3^{a}$ & $71.4^{\mathrm{a}}$ & $100.1^{b}$ & 6.58 & 0.009 \\
\hline
\end{tabular}

${ }^{1}$ Co-EDTA was added to the milk replacer as marker.

2 Ytterbium(III)oxide $\left(\mathrm{Yb}_{2} \mathrm{O}_{3}\right)$ was added to the concentrates as marker.

${ }^{3}$ Chromium mordant chopped straw (for the LowSF, MiddleSF, and HighSF treatments) or long hay (for the Hay treatment). 


\section{Discussion}

Animal performance was good throughout the experiment, and, in line with the paired gain strategy, unaffected by the dietary treatments.

\subsection{Fecal Excretion Curves of Ingestible Markers}

The time to peak ( $h$ ) is a measure for the total-tract retention time, i.e., the passage of digesta through the total digestive tract. For MR replacer, this represents the abomasum, small intestines, and the large intestines, because MR is assumed to bypass the rumen by means of the esophageal groove reflex (Berends et al., 2015). The time to peak of MR in the current study averaged (taken all dietary treatments into account) $12.4 \mathrm{~h}$. This is close to the total-tract retention time reported for MR in literature. In the study of Gilbert et al. (2017), involving 117 veal calves with an age of 7 to 8 weeks of age at the moment of sampling, a total-tract retention of $12.2 \mathrm{~h}$ for MR was reported.

The TMRT for concentrates and roughages depends on many factors, including physical feed characteristics (e.g., particle size), animal-related factors (e.g., feed intake level), and diet-related characteristics (e.g., forage quality) (Warner et al., 2013b). The time to peak in the current study was (on average) $21.4 \mathrm{~h}$ for concentrates, $59.1 \mathrm{~h}$ for straw and $36.8 \mathrm{~h}$ for hay. These values are within the ranges reported in literature for lactating dairy cattle. Ahvenjärvi et al. (2010) reported TMRT of 24.7 h for lanthanum labelled rapeseed meal for dairy cows fed $40 \%$ concentrates (on DM basis) in silagebased diets. This is similar to the values reported in the current study, although Warner et al. (2013a) estimated a TMRT of 40.9 - 42.0 h for a Cr-NDF mordanted concentrate mixture for dairy cows fed approximately 25 and 50\% concentrates (on DM basis) respectively, and Colucci et al. (1990) estimated a TMRT of 35.0 - $35.9 \mathrm{~h}$ for Cr-mordanted soybean meal for dairy cows fed similar levels of concentrates. For dairy cattle, Lund et al. (2006) reported TMRT values of 39.3 and $47.0 \mathrm{~h}$ for lucerne hay and 47.5 and $55.4 \mathrm{~h}$ when using fecal sampling.

In ruminants, the level of feed intake is linearly related with the rate of digesta flow from the abomasum (329 $\mathrm{mL} / \mathrm{h}$ for each $\mathrm{kg}$ feed intake/d) and with the flow along the small intestine (transit time; -54.9 min for each $\mathrm{kg}$ feed intake/d) (Gregory et al., 1985). This applies to the digesta present, consisting of $M R$, concentrates and roughages. Hence, assuming that (1) the time to peak $(h)$ is a measure for the total-tract retention time, and that (2) the time to peak of MR (i.e., $12.4 \mathrm{~h}$ ) represents the flow of digesta from the abomasum to the end of the large intestines, we can calculate the ruminal retention time of the concentrates, straw, and hay. When subtracting $12.4 \mathrm{~h}$ from the time to peak of the total tract measured for concentrates, straw, and hay, the ruminal retention time becomes 9.0, 46.7, and $24.4 \mathrm{~h}$ for concentrates, straw, and hay, respectively. Subsequently, rumen fractional passage rates were assumed constant and estimated according to Berends et al. (2015), resulting in rumen fractional passage rates of $11.1,2.1$, and $4.5 \% / h$ for concentrates, straw and hay, respectively. The fractional passage rate of straw is close to the value reported by Berends et al. (2015) for veal calves receiving high SF level diets (i.e., $1.65 \% / h$ on average), but the fractional passage rate of concentrates in the current study is considerably higher. The fractional passage rate of hay of the current study is close to the fractional passage rate of hay (i.e., on average $4.6 \% / h$ ) that has been reported before by Lallès and Poncet (1990) measured from fecal kinetics. The fractional passage rate of hay appears to be higher than that of straw, which is in line with the hay having a higher digestibility than straw ( 70 vs. $42 \%$ organic matter digestibility; CVB, 2018).

When considering the time to peak of the roughage (Table 5), excluding the Hay treatment, there is a numeric decline in the time to peak with increasing level of SF level (negative relation). This is to be expected, because in adult ruminants (like dairy cattle), increased feed intake generally results in an increased passage rate in the rumen, which was also observed for concentrates and roughage in veal calves by Berends et al. (2015). However, no relation was found ( $r=-0.252, P=0.188$ ) between the SF level of the straw-based diets (i.e., 20,30 or $40 \mathrm{~g} / \mathrm{kg} \mathrm{BW}^{0.75}$ ) and the time to peak of the roughage (excluding the Hay treatment) in the current study. 
Hence, the SF level appears not to affect the passage kinetics of roughage in veal calves. This is contrary to what was observed by Berends et al. (2015), where the SF level did affect passage kinetics of roughage. The current study differs from the study of Berends et al. (2015) in both the level of SF as well as the roughage fraction in the SF. The level of SF of the current study was slightly lower than that

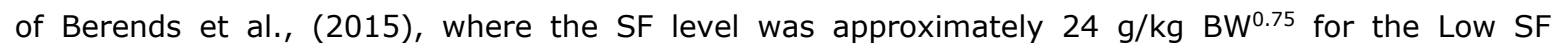
treatments and $50 \mathrm{~g} / \mathrm{kg} \mathrm{BW}{ }^{0.75}$ for the high SF treatments (based on calculations of Berends et al. (2014, 2015)). Additionally, the roughage fraction in the SF was lower in the current study ( $90: 10$ concentrate to roughage ratio) compared with Berends et al. (2015; 80:20 as well as 50:50 concentrate to roughage ratio). Particularly the latter might be related to the lack of relationship found in the current study. When the concentrate to roughage ratio is different than $90: 10$, for example $80: 20$ or 70:30, resulting is a higher fraction of roughage in the SF, effects of SF level on passage kinetics might be found. Especially when the roughage stimulates rumination. This appears to be true for the Hay treatment.

The Hay treatment affected the passage kinetics of roughage. The time to peak ( $h$ ) for the Hay treatment occurred considerably earlier than the time to peak $(h)$ for the roughage of the straw containing diets. As time to peak is a measure for the passage rate through the digestive tract, hay appears to have a higher passage rate than straw. This might be related with hay having a higher digestibility than straw (70 vs. $42 \%$ organic matter digestibility; CVB, 2018), and with long hay stimulating rumination and potentially rumen motility. Hay is thought to have a beneficial influence on rumen function: due to increased fermentation, hay should lead to better papillae development (Suárez et al., 2007). Longer particles of roughage (long hay vs. chopped straw) take longer to chew and ruminate before the particle length is sufficiently reduced to move from the reticulorumen to the abomasum. This increased rumination increases salivation, and saliva secretion subsequently increases the buffering capacity of rumen fluid (de Boever et al., 1990; González et al., 2012). Additionally, prolonged presence of roughage particles in the rumen improves rumen motility (Morisse et al., 1999).

\subsection{Multicompartmental Model}

The roughage and the concentrates of the diets enter the rumen, the compartment of the digestive tract with most likely the longest MRT. Based on the multicompartmental model of Dhanoa et al. (1985), the MRT of the slowest compartment can be determined (as described in the calculations section of the materials and methods). Unfortunately, for the concentrates (for which the marker $\mathrm{Yb}_{2} \mathrm{O}_{3}$ was used), the multicompartmental model of Dhanoa et al. (1985) could only be fitted on 11 out of the 39 individual calves (i.e., 1 calf receiving LowSF, 5 calves receiving HighSF, and 5 calves receiving Hay). It was therefore not possible to determine the CMRT1 - the MRT of the rumen.

For the roughage (for which the marker Cr-NDF was used), the multicompartmental model of Dhanoa et al. (1985) could be fitted on 22 out of the 39 individual observation (i.e., 2 calves receiving LowSF, 5 calves receiving MiddleSF, 6 calves receiving HighSF, and 9 calves receiving Hay). For these 22 individual observations, $\mathrm{K}_{1}, \mathrm{~K}_{2}, \mathrm{CMRT1}, \mathrm{CMRT2}, \mathrm{TT}$, TMRT, and PCT were calculated. Subsequently, based on these 22 observations, a prediction equation for PCT (i.e., moment excretion pattern reaches peak concentration) was developed with only tmax (i.e., time to peak; van den Borne et al., 2007) as dependent variable $(r=0.89, P<0.001)$, as well as a prediction equation for $K_{1}$ (i.e., the fractional rate constants for the compartment in the digestive tract with the longest retention time) with only PCT as dependent variable $(r=0.83, P<0.001)$. Based on these prediction equations, the PCT, K 1, TMRT, and CMRT1 were subsequently also calculated for the observations where the multicompartmental model of Dhanoa et al. (1985) did not fit properly $(n=17)$.

The PCT (i.e., the moment when excretion curve reaches peak concentration) of the multicompartmental model of Dhanoa et al. (1985) is closely related with the tmax using the equations of van den Borne et al. (2007), with $r=0.94(P<0.001)$, illustrating that both methods can describe the fecal excretion of Cr-NDF sufficient. However, the level is considerably different, with on average a PCT of $100.1 \mathrm{~h}$ and a tmax of $53.5 \mathrm{~h}$. The CMRT1, calculated using the multicompartmental model of Dhanoa et al. (1985), was 14.6, 17.4, 33.1, and $34.1 \mathrm{~h}$ for LowSF, MiddleSF, HighSF, and Hay treatment, respectively. The CMRT1 for LowSF was lower than the CMRT1 of Hay $(P=0.038)$ and tended to be lower than the CMRT1 of HighSF $(P=0.052)$. 
This suggest that the roughage remains in the rumen for a longer period of time with a higher SF level, which was also observed $(r=0.49, P=0.002)$. This is confirmed by the $K_{1}$ (fractional passage rate of the slowest compartment) calculated using the multicompartmental model of Dhanoa et al. (1985). The $K_{1}$ was $0.050,0.042,0.036$, and $0.031 \%$ h for LowSF, MiddleSF, HighSF, and Hay, respectively with no effect of treatment $(P=0.268)$, but with $K_{1}$ related with SF level $(r=-0.32, P=0.049)$. This illustrates that the fractional passage rate of the rumen decreases with increasing SF level, which is contrary to what has been previously observed in veal calves (Berends et al., 2015), dairy calves (Broesder et al., 1990), as well as in adult ruminants (Owens and Goetsch, 1986; Robinson et al., 1987; Colucci et al., 1990). The increase in SF intake has previously been associated with increased rumen contents and rumen fluid volume (Berends et al., 2015; Owens and Goetsch, 1986). An increased rumen volume enables a longer retention time and thus greater feed degradation, which may also explain the decrease in fractional passage rate. This observation is in agreement with the results in pigs of Schop et al. (2019). Recently, Schop et al. (2019) showed that the MRT in the stomach of growing pigs of both solids and liquid increased for both solids and liquids when feed intake was increased using low-soluble nutrients. This is contrary to adult cattle, but in comparison to adult cattle, the rumen of calves is still in development and the gastro-intestinal tract is more comparable to that of monogastric animals. The volatile fatty acids produced in the rumen do not represent the main energy supply. The largest part of the gross energy provided to veal calves still originates from MR ( $50-75 \%)$. When a calf ingests $M R$, the esophageal groove closes, allowing the MR to by-pass the rumen (Abe et al., 1979). Hence, the MR flows directly into the abomasum and subsequently into the small intestines. The nutrients of the MR are therefore enzymatically hydrolyzed and absorbed in the small intestines, whereas the solid feed enters the rumen to be fermented by the microbial population. This is to a certain extent similar to monogastric animals.

\subsection{Recovery of ${ }^{13} \mathrm{C}$ Tracers in Breath}

According to Hird et al. (1966), there is little transport of the unmetabolized fatty acid octanoate across the rumen epithelium. Additionally, fatty acids are not fermented in the rumen (Beauchemin et al., 2008) and octanoate is an saturated fatty acid, which does not enter the biohydrogenation pathway (Bauman and Griinari, 2003). Hence, it was expected that $\left[1-{ }^{13} \mathrm{C}\right]$ octanoate can serve as an inert marker, suitable for passage rate kinetic measurements via the ${ }^{13} \mathrm{C}$ breath test.

To determine whether the non-invasive ${ }^{13} \mathrm{C}$ tracer breath test approach can serve as an alternative for the fecal excretion curves of indigestible markers to determine the passage kinetics in veal calve, the time to peak enrichment of $\mathrm{CO}_{2}$ following $\left[1-{ }^{13} \mathrm{C}\right]$ octanoate ingestion measured in the $\mathrm{CRC}$ was compared with the time to peak of $\mathrm{Yb}$ measured in feces after an oral dose of $\mathrm{Yb}_{2} \mathrm{O}_{3}$. There appears to be no relation between the passage kinetics of concentrates determined using the ${ }^{13} \mathrm{C}$ tracers in breath (via $\left[1^{13} \mathrm{C}\right]$ octanoate) and the fecal excretion of an indigestible marker (via $\left.\mathrm{Yb}_{2} \mathrm{O}_{3}\right) ; r=0.135$ and $P=$ 0.433 . Also the time to peak ( $h$; a measure for passage rate through the digestive tract) differs considerably between the 2 methods. Where the time to peak ranges between 1.93 and $2.12 \mathrm{~h}$ when using the ${ }^{13} \mathrm{C}$ tracers in breath, the time to peak ranges between 19.5 and $22.5 \mathrm{~h}$ when using the fecal excretion of an indigestible marker - a difference of almost $20 \mathrm{~h}$. This difference is most likely due to $\left[1-{ }^{13} \mathrm{C}\right]$ octanoate not being as inert as we expected. The ${ }^{13} \mathrm{C}$ carboxyl group of $\left[1-{ }^{13} \mathrm{C}\right]$ octanoate was either detached from $\left[1-{ }^{13} \mathrm{C}\right]$ octanoate in the rumen or replaced by another carboxyl group in the rumen. Hence, the time to peak of the ${ }^{13} \mathrm{C}$ breath test represents most likely the oro-duodenal transit, whereas the fecal excretion curves is a measure for oro-fecal transit, making $\left[1-{ }^{13} \mathrm{C}\right]$ octanoate in combination with the ${ }^{13} \mathrm{C}$ breath test unsuitable for measuring the passage kinetics of concentrates. 


\section{Conclusions}

The aims of this study were (1) to provide reliable estimates of total tract mean retention times of milk replacer, concentrates, and roughage, (2) to determine the effect of SF level and type of roughage on passage kinetics of milk replacer, concentrates, roughage in veal calves, and (3) to compare passage kinetics in veal calves using the fecal excretion curves of indigestible markers as well as a non-invasive ${ }^{13} \mathrm{C}$ tracer breath test approach to determine whether the later technique can serve as an alternative. The results of this study indicate that the total-tract retention of milk replacer in veal calves, based on fecal excretion curves, was on average $12.4 \mathrm{~h}$, and that the passage kinetics of the milk replacer was not affected by the level of solid feed (i.e., roughage and concentrate). Additionally, based on the results of the fecal excretion curves, it can be concluded that the total-tract retention of concentrates was shorter (on average $21.4 \mathrm{~h}$ ) than that of both straw $(59.1 \mathrm{~h}$ ) and hay $(36.8 \mathrm{~h}$ ), and that the total-tract retention of concentrates and straw was not affected by the level of solid feed. The type of roughage only affected the passage of roughage, with long hay having a faster passage rate than chopped straw. This might be related with hay having a higher digestibility than straw and with long hay stimulating rumination and potentially rumen motility. Furthermore, based on the ${ }^{13} \mathrm{C}$ breath test, it can be concluded that the ${ }^{13} \mathrm{C}$ tracer $\left[1^{-13} \mathrm{C}\right]$ octanoate cannot serve as an alternative to measure passage kinetics of concentrates using the fecal excretion method through the digestive tract of veal calves. 


\section{$6 \quad$ Acknowledgments}

Liliana Amado Barrantes, Emma Beijer, Tom Bastiaansen, Eline Holtslag, Pieter Knoop, Jeroen Snijders, and Saskia van Zon (students of Wageningen University \& Research, Wageningen, the Netherlands), as well as André Jansen, Bjorge Laurenssen, Guus Nijeboer, Henk Schilder, Piet van Wikselaar, Sabine van Woudenberg, and Tamme Zandstra (staff of the experimental facilities "Carus" as well as of Wageningen University \& Research, Wageningen, the Netherlands) are gratefully acknowledged for their assistance during the implementation of the experiment, as are the laboratory staff of the Animal Nutrition Group (Wageningen, the Netherlands). 


\section{References}

Abe, M., T. Iriki, K. Kondoh, and H. Shibui. 1979. Effects of nipple or bucket feeding of milk-substitute on rumen by-pass and on rate of passage in calves. Br. J. Nutr. 41:175-181.

Ahvenjärvi, S., M. Rinne, T. Heikkilä, and P. Huhtanen. 2010. The effect of a diet and intrinsic characteristics of feed particles on passage kinetics in dairy cows. In: P. Udén, T. Eriksson, C.E. Müller, R. Spörndly, and M. Liljeholm (eds.), Proceedings of 1st Nordic Feed Science Conference, Uppsala, Sweden, pp. 162-165.

Alferink, S. J. J., J. J. G. C. van den Borne, W. J. J. Gerrits, S. C. W. Lammers-Wienhoven, and M. J. W. Heetkamp. 2003. On-line, continuous determination of ${ }^{13} \mathrm{CO}_{2} /{ }^{12} \mathrm{CO}_{2}$ ratios by non-dispersive infrared absorption in indirect calorimetry facilities. In: Souffrant WB, Metges CC, editors. Progress in research on energy and protein metabolism. Rostock-Warnemünde (Germany): Wageningen Academic Publishers, 465-468.

Bauman, D. E., and J. M. Griinari. 2003. Nutritional regulation of milk fat synthesis. Annu. Rev. Nutr. 23:203-227.

Berends, H., J. J. G. C. van den Borne, N. Stockhofe-Zurwieden, M. S. Gilbert, T. Zandstra, W. F. Pellikaan, C. G. van Reenen, E. A. M. Bokkers, and W. J. J. Gerrits. 2015. Effects of solid feed level and roughage-to-concentrate ratio on ruminal drinking and passage kinetics. J. Dairy Sci. 98:5621-5629.

Beauchemin, K. A., M. Kreuzer, F. O'Mara, and T. A. McAllister. 2008. Nutritional management for enteric methane abatement: A review. Aust. J. Exp. Agric. 48:21-27.

Bibby, J. and H. Toutenburg. 1977. Prediction and improved estimation in linear models. Chichester (UK): John Wiley \& Sons.

Broesder, J. T., M. B. Judkins, L. J. Krysl, S. A. Gunter, and R. K. Barton. 1990. Thirty or sixty percent milk replacer reduction for calves: Effects on alfalfa hay intake and digestibility, digestive kinetics and ruminal fermentation. J. Anim. Sci. 68:2974-2985.

Colucci, P.E., G.K. MacLeod, W.L. Grovum, I. McMillan, and D.J. Barney. 1990. Digesta kinetics in sheep and cattle fed diets with different forage to concentrate ratios at high and low intakes. J. Dairy Sci. 73: 2143-2156.

CVB. 2018. Chemische samenstellingen en nutritionele waarden van voedermiddelen (in Dutch). CVB (Centraal Veevoederbureau), The Hague, the Netherlands.

de Boever, J. L., J. I. Andries, D. L. de Brabander, B. G. Cottyn, and F. X. Buysse. 1990. Chewing activity of ruminants as a measure of physical structure - A review of factors affecting it. Anim. Feed Sci. Tech. 27:281-291.

Gilbert, M. S., A. J. Pantophlet, J. J. G. C. van den Borne, W. H. Hendriks, H. A. Schols, and W. J. J. Gerrits. 2016. Effects of replacing lactose from milk replacer by glucose, fructose, or glycerol on energy partitioning in veal calves. J. Dairy Sci. 99:1121-1132.

González, L. A., X. Manteca, S. Calsamiglia, K. S. Schwartzkopf-Genswein, and A. Ferret. 2012. Ruminal acidosis in feedlot cattle: Interplay between feed ingredients, rumen function and feeding behavior (a review). Anim. Feed Sci. Tech. 172: 66-79.

Gregory, P. C., S. Miller, and A. Brewer. 1985. The relation between food intake and abomasal emptying and small intestinal transit time in sheep. Br. J. Nutr. 53:373-380.

Heetkamp, M. J. W., S. J. J. Alferink, T. Zandstra, P. Hendriks, H. van den Brand, and W. J. J. Gerrits. 2015. Design of climate respiration chambers, adjustable to the metabolic mass of subjects. Pages 35-56 in Indirect Calorimetry. Techniques, Computations and Applications. W. J. J. Gerrits and E. Labussière, ed. Wageningen Academic Publishers, Wageningen, the Netherlands.

Hird, F. J. R., R. B. Jackson, and M. J. Weidemann. 1966. Transport and metabolism of fatty acids by isolated rumen epithelium. Biochem. J. 98:394-400.

International Organization for Standardization. 1998. ISO 6496:1998. Animal feeding stuffs Determination of phosphorus content - spectrometric method. International Organization for Standardization, Geneva, Switzerland. 
International Organization for Standardization. 1998. ISO 6496:1998. Animal feeding stuffs Determination of moisture and other volatile matter content. International Organization for Standardization, Geneva, Switzerland.

International Organization for Standardization. 1998. ISO 9831:1998. Animal feedstuffs, animal products, and faeces or urine - Determination of gross caloric values-Bomb calorimeter method. International Organization for Standardization, Geneva, Switzerland.

International Organization for Standardization. 2003. ISO 5984:2003. Animal feeding stuffs Determination of crude ash. International Organization for Standardization, Geneva, Switzerland.

International Organization for Standardization. 2008. ISO 16634-1:2008. Determination of total nitrogen content by combustion according to the Dumas principle and calculation of crude protein content. Part 1: oilseeds and animal feeding stuffs. International Organization for Standardization, Geneva, Switzerland.

International Organization for Standardization. 2017. ISO 15510:2017. Animal feeding stuffs - Methods of sampling and analysis - Determination of calcium, sodium, phosphorus, magnesium, potassium, iron, zinc, copper, manganese, cobalt, molybdenum and lead by ICP-AES. International Organization for Standardization, Geneva, Switzerland.

Labussière, E., H. Berends, M. S. Gilbert, J. J. G. C. van den Borne, and W. J. J. Gerrits. 2014. Estimation of milk leakage into the rumen of milk-fed calves through an indirect and repeatable method. Anim. 8:1643-1652.

Lallès, J. P., and C. Poncet. 1990. Rate of passage of digesta during and after weaning in calves fed concentrate diets containing pea or soya-bean meal. Livest. Prod. Sci. 24:333-345.

López S., J. France, W. J. J. Gerrits, M. S. Dhanoa, D . J. Humphries, and J. Dijkstra. 2000. A generalized Michaelis-Menten equation for the analysis of growth. J. Anim. Sci. 78:1816-1828.

Lund, P., M.R. Weisbjerg, and T. Hvelplund. 2006. Passage kinetics of fiber in dairy cows obtained from duodenal and faecal ytterbium excretion. Effect of forage type. Anim. Feed Sci. Technol. 128: 229-252.

McCue, M. D., and K. C. Welch. 2016. ${ }^{13} \mathrm{C}$-Breath testing in animals: theory, applications, and future directions. J. Comp. Physiol. B: Biochemical, Systemic, and Environmental Physiology 186: 265285.

Morisse, J. P., J. P. Cotte, D. Huonnic, and A. Martrenchar. 1999. Influence of dry feed supplements on different parameters of welfare in veal calves. Anim. Welfare 8:43-52.

Owens, F., and A. Goetsch. 1986. Digesta passage and microbial protein synthesis. Pages 196-223 in Control of Digestion and Metabolism in Ruminants. L. Milligan, W. Grovum, and A. Dobson, ed. Prentice-Hall, Englewood Cliffs, NJ.

Pellikaan, W. F., J. Dijkstra, S. Tamminga, H. Boer, S. C. W. Lammers-Wienhoven, W. J. H. van Gestel, and G. Hof. 2004. Passage of ${ }^{13} \mathrm{C}$-labelled grass silage through the gastro-intestinal tract of dairy cows at two levels of feed intake. Pages 31-56 in PhD dissertation entitled Passage of ${ }^{13} \mathrm{C}$ labelled feed components through the digestive tract of dairy cows.

Pellikaan, W. F., M. W. A. Verstegen, S. Tamminga, J. Dijkstra, and W. H. Hendriks. 2013. $\delta^{13} \mathrm{C}$ as a marker to study digesta passage kinetics in ruminants: A combined in vivo and in vitro study. Animal 7:754-767.

Schop, M., A. J. M. Jansman, S. de Vries, and W. J. J. Gerrits. 2019. Increasing intake of dietary soluble nutrients affects digesta passage rate in the stomach of growing pigs. Br. J. Nutr. 121:529-537.

Stahel, P., J. A. R. MacPherson, H. Berends, M. A. Steele, and J. A. Cant. 2017. Short communication: Parameters of abomasal emptying and glucose-insulin dynamics in Holstein-Friesian calves at 2 ages and 2 levels of milk replacer intake. J. Dairy Sci. 100:5068-5072.

Suarez, B. J., C. G. Van Reenen, N. Stockhofe, J. Dijkstra, and W. J. J. Gerrits. 2007. Effect of roughage source and roughage to concentrate ratio on animal performance and rumen development in veal calves. J. Dairy Sci. 90:2390-2403.

Robinson, P. H., S. Tamminga, and A. M. van Vuuren. 1987. Influence of declining level of feed intake and varying the proportion of starch in the concentrate on rumen ingesta quantity, composition and kinetics of ingesta turnover in dairy cows. Livest. Prod. Sci. 17:37-62.

van den Borne, J. J. G. C., G. E. Lobley, M. W. A. Verstegen, J.-M. Muijlaert, S. J. J. Alferinkg, and Walter J. J. Gerrits. 2007. Body fat deposition does not originate from carbohydrates in milk-fed calves. J. Nutr. 137:2234-2241. 
Udén, P., P. E. Colucci, and P. J. Van Soest. 1980. Investigation of chromium, cerium and cobalt as markers in digesta rate of passage studies. J. Sci. Food Agric. 31:625-632.

van Gastelen, S., M.H.P.W. Visker, J.E. Edwards, E.C. Antunes-Fernandes, K.A. Hettinga, S.J.J. Alferink, W.H. Hendriks, H. Bovenhuis, H. Smidt, and J. Dijkstra. 2017. Linseed oil and DGAT1 K232A polymorphism: effects on methane emission, energy and $\mathrm{N}$ metabolism, lactation performance, ruminal fermentation, and rumen microbial composition of Holstein-Friesian cows. J. Dairy Sci. 100:8939-8957.

Warner, D., J. Dijkstra, S. Tamminga, and W. F. Pellikaan. 2013a. Passage kinetics of concentrates in dairy cows measured with carbon stable isotopes. Anim. 7:1935-1943.

Warner, D., J. Dijkstra, W. H. Hendriks, and W. F. Pellikaan. 2013b. Stable isotope-labelled feed nutrients to assess nutrient-specific feed passage kinetics in ruminants. J. Sci. Food Agric. 94:819-824. 

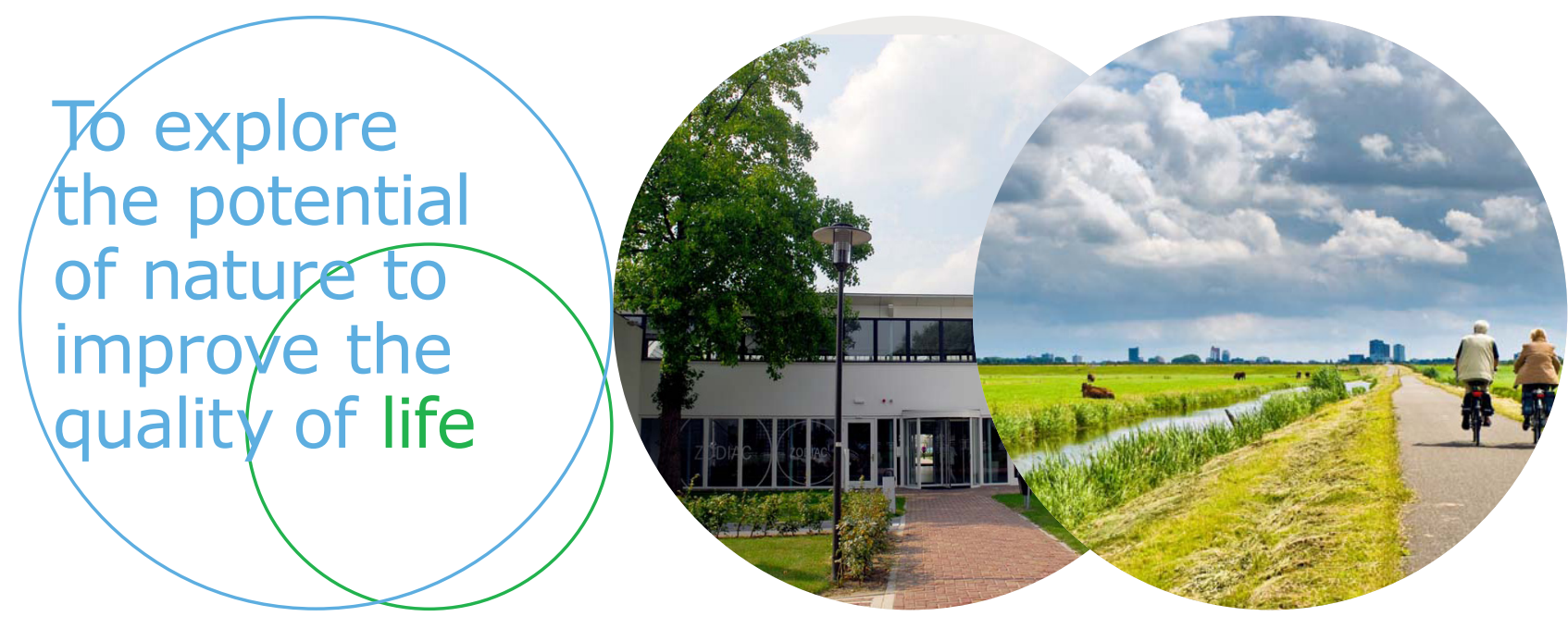

Wageningen Livestock Research P.O. Box 338

6700 AH Wageningen

The Netherlands

$\mathrm{T}+31(0) 317483953$

E info.livestockresearch@wur.nl

www.wur.nl/livestock-research

Wageningen Livestock Research creates science based solutions for a sustainable and profitable livestock sector. Together with our clients, we integrate scientific knowledge and practical experience to develop livestock concepts for future generations.

Wageningen Livestock Research is part of Wageningen University \& Research. Together we work on the mission: 'To explore the potential of nature to improve the quality of life'. A staff of 6,500 and 10,000 students from over 100 countries are working worldwide in the domain of healthy food and living environment for governments and the business community-at-large. The strength of Wageningen University \& Research lies in its ability to join the forces of specialised research institutes and the university. It also lies in the combined efforts of the various fields of natural and social sciences. This union of expertise leads to scientific breakthroughs that can quickly be put into practice and be incorporated into education. This is the Wageningen Approach. 